\title{
Integration of the Experimental Results of a Parabolic Trough Collector (PTC) Solar Plant to an Absorption Air-Conditioning System
}

\author{
Yuridiana Rocio Galindo Luna ${ }^{1}$, Wilfrido Rivera Gómez Franco ${ }^{1}$, Ulises Dehesa Carrasco ${ }^{3}$, \\ Rosenberg Javier Romero Domínguez ${ }^{2} \mathbb{D}$ and José Camilo Jiménez García ${ }^{1, *}$ (D) \\ 1 Instituto de Energías Renovables, Universidad Nacional Autónoma de México, Privada Xochicalco S/N, \\ Colonia Centro, C.P. 62580 Temixco, Morelos, Mexico; ygalu@ier.unam.mx (Y.R.G.L.); \\ wrgf@ier.unam.mx (W.R.G.F.) \\ 2 Centro de Ingeniería y Ciencias Aplicadas, Universidad Autónoma del Estado de Morelos, \\ Av. Universidad no. 1001, C.P. 62209 Cuernavaca, Morelos, Mexico; rosenberg@uaem.mx \\ 3 Catedrático CONACYT, Instituto Mexicano de Tecnología del Agua, Paseo Cuahunáhuac, \\ C.P. 62580 Jiutepec, Morelos, Mexico; udehesaca@conacyt.mx \\ * Correspondence: jcjig@ier.unam.mx; Tel.: +52-777-249-2189
}

Received: 26 September 2018; Accepted: 25 October 2018; Published: 5 November 2018

\begin{abstract}
The present study reports the experimental results of a parabolic trough collector field and an absorption cooling system with a nominal capacity of $5 \mathrm{~kW}$, which operates with the ammonia-lithium nitrate mixture. The parabolic trough collectors' field consists of 15 collectors that are made of aluminum plate in the reflector surface and cooper in the absorber tube, with a total area of $38.4 \mathrm{~m}^{2}$. The absorption cooling system consists of 5 plate heat exchangers working as the main components. Parametric analyses were carried out to evaluate the performance of both systems under different operating conditions, in independent way. The results showed that the solar collectors' field can provide up to $6.5 \mathrm{~kW}$ of useful heat to the absorption cooling system at temperatures up to $105{ }^{\circ} \mathrm{C}$ with thermal efficiencies up to $19.8 \%$ and exergy efficiencies up to 14.93 , while the cooling system operated at generation temperatures from $85-95{ }^{\circ} \mathrm{C}$ and condensation temperatures between 20 and $28^{\circ} \mathrm{C}$, achieving external coefficients of performance up to 0.56 , cooling temperatures as low as $6^{\circ} \mathrm{C}$, and exergy efficiencies up to 0.13 . The highest value for the solar coefficient of performance reached 0.07 .
\end{abstract}

Keywords: parabolic trough collector; absorption cooling system; thermal efficiency; useful heat; ammonia-lithium nitrate

\section{Introduction}

During the last decades, the energy demand required to activate the conventional air-conditioning systems has increased due to the growing population. The countries with warm conditions need to use air-conditioning systems to achieve comfortable conditions [1]. In the case of Mexico, this country has four climatic regions: arid, dry tropic, mild weather and humid tropic [2]. In Mexico, 5.2 million air-conditioning units were installed in the Mexican households in 2011 [3]. Thus, conditioned households were calculated to be $19.5 \%$ of the total, however, if it is considered the annual growing rate as $7.5 \%$ [4], in 2015, the average number of households with air-conditioning devices was determined at 6.9 million. Therefore, the electricity demand estimated for air-conditioning was $11.8 \mathrm{TW} / \mathrm{h}$ in 2015, increased 2.9 TW/h with respect at $8.9 \mathrm{TW} / \mathrm{h}$ calculated in 2011 [5]. This fact means that we must find an alternative option for mitigating the energy demand. 
Solar energy is an alternative option because it is the most abundant energy source on earth. Thanks to its favorable geographic location, Mexico can use solar technologies [6]. As a very convenient option. To take advance of solar energy, a wide range of solar collectors can be used, however, one of the more advanced technology is the parabolic trough collector (PTC) [7]. Several authors have reported the performance of several air-conditioning systems driven by solar technologies, such as $\mathrm{Li}$ et al. [8], who reported about the performance of $\mathrm{LiBr}-\mathrm{H}_{2} \mathrm{O}$ absorption chiller of $4.7 \mathrm{~kW}$ cooling capacity for a traditional and partitioned storage tank. The system was installed at the University of Hong Kong and employed a set of flat-plate collectors covering an area equivalent to $38 \mathrm{~m}^{2}$ and a storage tank with a volume of $2.73 \mathrm{~m}^{3}$. The results calculated COP was $0.07(15 \%$ higher than traditional tank mode). Syed et al. [9] evaluated a $\mathrm{LiBr}-\mathrm{H}_{2} \mathrm{O}$ absorption air-conditioning unit ( $\left.35 \mathrm{~kW}\right)$ and $49.9 \mathrm{~m}^{2}$ flat-plates collectors designed for cooling for a typical Spanish house. The results show the cooling effect was provided by $8.6 \mathrm{~h}$, the maximum cooling capacity was $7.5 \mathrm{~kW}$. The average COP was 0.6 during the period. Rodríguez et al. [10] analyzed an experimental solar absorption cooling system installed at the University Carlos III in Madrid. The system consists of $50 \mathrm{~m}^{2}$ flat plate solar collectors model Vitosol 100 coupled to a Yazaki absorption machine, it uses $\mathrm{LiBr}-\mathrm{H}_{2} \mathrm{O}$. According to the results, the average cooling capacity was $3 \mathrm{~kW}$ during the summer season, the cooling period was $6.5 \mathrm{~h}$, and the COP was 0.7 . The collectors' field can supply $56 \%$ of cooling demand. Rosiek and Batlles [11] studied the behavior of a solar air-conditioning system in Almeria in the south of Spain. The cooling system consists of a Yazaki absorption chiller with a capacity of $70 \mathrm{~kW}$, which uses $\mathrm{LiBr}-\mathrm{H}_{2} \mathrm{O}$. Single-glazed flat plate collectors with $160 \mathrm{~m}^{2}$ area were coupled to the absorption machine. The evaluation showed that a generation temperature under $84^{\circ} \mathrm{C}$, the chilled water achieved is in a range from 10 to $13^{\circ} \mathrm{C}$ and the cooling water temperature was $27-28^{\circ} \mathrm{C}$, with these conditions, they obtained a cooling capacity at $40 \mathrm{~kW}$ and a COP of 0.6. Marc et al. [12] studied an experimental solar absorption cooling system installed in Saint Pierre in Reunion Island. The solar field consists of 36 double-glazed flat plate solar collectors $\left(90 \mathrm{~m}^{2}\right.$ area) coupled to single-effect absorption chiller that uses $\mathrm{LiBr}-\mathrm{H}_{2} \mathrm{O}$ as working fluid with cooling capacity at $30 \mathrm{~kW}$. The maximum electrical coefficient of performance was 1.65. The temperatures for the absorption system are as follows: generator, absorber and evaporator were $90{ }^{\circ} \mathrm{C}, 30^{\circ} \mathrm{C}$ and $11^{\circ} \mathrm{C}$ respectively. Sanjuan et al. [13] optimized the performance of a solar cooling system that includes four absorption units Climatewell CW10, these using $\mathrm{LiBr}-\mathrm{H}_{2} \mathrm{O}(80 \mathrm{~kW}$ total cooling capacity) and $170 \mathrm{~m}^{2}$ area of Unisol CP1-TIM flat plates, this system was installed in Almeria, Spain. González-Gil et al. [14] reported the experimental air-cooled absorption prototype that uses $\mathrm{LiBr}-\mathrm{H}_{2} \mathrm{O}$ (3.8 $\mathrm{kW}$ cooling capacity). The solar system consisted of $48 \mathrm{~m}^{2}$ of flat-plate collectors. The COP was around 0.6 , which represents about $85 \%$ of the cycle normal capacity. Martínez et al. [15] analyzed the performance of a solar cooling system in Alicante, Spain. The Yazaki absorption chiller uses $\mathrm{LiBr}-\mathrm{H}_{2} \mathrm{O}$ and offers a cooling capacity of $17.6 \mathrm{~kW}$. The system was driven with a flat plate collector field with $38.4 \mathrm{~m}^{2}$. According to with the results, the average solar energy received was $7.14 \mathrm{~kW}$ h per square meter of collector area was the average solar incident, the energy transfer to the storage tank was calculated of $29 \%$ and the average COP was 0.691 . Zhai et al. [16] evaluated a $\mathrm{LiBr}-\mathrm{H}_{2} \mathrm{O}$ absorption chiller of $8 \mathrm{~kW}$ cooling capacity installed in Shanghai Jian Tong University. The solar system consists of evacuated collectors with a compound parabolic collector $\left(96 \mathrm{~m}^{2}\right)$ and a storage tank with a volume capacity of $3 \mathrm{~m}^{3}$. According to the results, the average solar efficiency was 0.46 , the cooling capacity was calculated as $4.5 \mathrm{~kW}$, and a COP of 0.32 was calculated considering the $8 \mathrm{~h}$ of the test length. Hai Quan et al. [17] analyzed the performance of an absorption cooling system $\left(\mathrm{LiBr}-\mathrm{H}_{2} \mathrm{O}\right)$ driven by solar collectors, this system was adopted in Changle, Shandong in China. The study was divided into three groups of solar collectors that used gravity assisted pipe and horizontal heat pipe evacuated with $1020 \mathrm{~m}^{2}$ total area. The air-conditioning system was operated during a period of 10:00 to 14:00, the temperature achieved by the collectors was in a range from 56 to $85.8^{\circ} \mathrm{C}$ and the chilled water temperature was reported in the range from 10 to $18^{\circ} \mathrm{C}$. The results showed the COP calculated varied from 0.28 to 0.34 when the efficiencies for the solar collector were between $40-45 \%$. Galindo et al. [18] reported the performance of an absorption cooling system operating with a $\mathrm{NaOH}-\mathrm{H}_{2} \mathrm{O}$ mixture 
and using as a hybrid heat source a parabolic trough plant coupled with a low enthalpy geothermal heat system, the results showed the average experimental storage tank temperature achieved by the parabolic trough plant was $93.8^{\circ} \mathrm{C}$ and the COP was calculated as 0.71 , under design conditions.

Regarding absorption cooling systems (ACS), until now there has been a couple of working mixtures that have been widely used in commercial and experimental units: the mixture water-lithium bromide $\left(\mathrm{H}_{2} \mathrm{O}-\mathrm{LiBr}\right)$ and the mixture ammonia-water $\left(\mathrm{NH}_{3}-\mathrm{H}_{2} \mathrm{O}\right)$, nevertheless, there are several well-known limitations related to their use, this fact has motivated the development of many studies proposing the use of not-conventional mixtures. Regarding the use of alternative mixtures, although the lithium chloride-water $\left(\mathrm{LiCl}-\mathrm{H}_{2} \mathrm{O}\right)$ mixture was proposed many years ago as an alternative mixture in absorption systems, recently, several research groups renewed their interest in the use of this mixture. Some of those studies are the following. Bellos et al. [19] carried out an energetic and exergetic comparison of the $\mathrm{LiCl}-\mathrm{H}_{2} \mathrm{O}$ and $\mathrm{LiBr}-\mathrm{H}_{2} \mathrm{O}$ working pairs in a solar absorption cooling system. The modeled system consisted of flat plate collectors, a storage tank, and a single effect absorption cooling system. Both mixtures were analyzed at different ambient and heat source temperatures. The results showed that the $\mathrm{LiCl}-\mathrm{H}_{2} \mathrm{O}$ pair showed a better performance than the $\mathrm{LiBr}-\mathrm{H}_{2} \mathrm{O}$ pair in all the studied cases. Moreover, it was demonstrated that the optimum heat source temperature for the $\mathrm{LiCl}-\mathrm{H}_{2} \mathrm{O}$ mixture was lower than that for the $\mathrm{LiBr}-\mathrm{H}_{2} \mathrm{O}$ mixture. Patel et al. [20] performed a thermodynamic analysis of a single effect absorption cooling system operating with the $\mathrm{LiCl}-\mathrm{H}_{2} \mathrm{O}$ and $\mathrm{LiBr}-\mathrm{H}_{2} \mathrm{O}$ working pairs. The authors reported that the maximum exergy destruction in the system occurs in the absorber and the generator. Also, the authors reported that the $\mathrm{LiCl}-\mathrm{H}_{2} \mathrm{O}$ mixture presented a better performance than the $\mathrm{LiBr}-\mathrm{H}_{2} \mathrm{O}$ mixture. Aman et al. [21] theoretically analyzed the performance of a bubble-pump-driven $\mathrm{LiCl}-\mathrm{H}_{2} \mathrm{O}$ and $\mathrm{LiBr}-\mathrm{H}_{2} \mathrm{O}$ absorption air conditioning systems. The authors reported that, under the same operating conditions, the system operating with the $\mathrm{LiCl}-\mathrm{H}_{2} \mathrm{O}$ achieved higher coefficients of performance and cooling capacities than those obtained with the $\mathrm{LiBr}-\mathrm{H}_{2} \mathrm{O}$ pair. Bellos et al. [22] modelled a double effect absorption cooling system driven by parabolic trough collectors operating with the $\mathrm{LiCl}-\mathrm{H}_{2} \mathrm{O}$ and $\mathrm{LiBr}-\mathrm{H}_{2} \mathrm{O}$ working pairs. The results showed that when the system operated with the $\mathrm{LiCl}-\mathrm{H}_{2} \mathrm{O}$ mixture the solar coefficient of performance was $8 \%$ higher than the obtained with the $\mathrm{LiBr}-\mathrm{H}_{2} \mathrm{O}$ mixture. Konwar and Gogoi $[23,24]$ reported two investigations on the energy and exergy performance of a double effect absorption refrigeration system operating with the $\mathrm{LiCl}-\mathrm{H}_{2} \mathrm{O}$ and $\mathrm{LiBr}-\mathrm{H}_{2} \mathrm{O}$ working pairs. The analysis showed that the system operating with the $\mathrm{LiCl}-\mathrm{H}_{2} \mathrm{O}$ achieved higher coefficients of performance and exergy efficiencies than the values obtained by the use of the $\mathrm{LiBr}-\mathrm{H}_{2} \mathrm{O}$ working pair.

On the other hand, in agreement with the literature reviews presented by Best and Rivera [25] and Rivera et al. [26], the use of the alternative working-pair composed of ammonia and lithium nitrate $\left(\mathrm{NH}_{3}-\mathrm{LiNO}_{3}\right)$ in an $\mathrm{ACS}$, could offer some advantages over the aforementioned mixtures in several aspects. For instance, compared with the ACS using $\mathrm{NH}_{3}-\mathrm{H}_{2} \mathrm{O}$, in the systems operating with $\mathrm{NH}_{3}-\mathrm{LiNO}_{3}$ is not necessary the use of a rectifier; also, as it was reported by Wu et al. $[27,28]$ and Boman et al. [29], the $\mathrm{NH}_{3}-\mathrm{LiNO}_{3}$ systems are able to operate at lower generation temperatures and higher condensation temperatures reaching higher values for the coefficient of performance at specific conditions. On the other hand, some of the advantages of a system using $\mathrm{NH}_{3}-\mathrm{LiNO}_{3}$ over one using $\mathrm{H}_{2} \mathrm{O}-\mathrm{LiBr}$ is that the former does not operate in vacuum conditions such as the latter. Furthermore, the $\mathrm{NH}_{3}-\mathrm{LiNO}_{3}$ mixture may be used not only for air-conditioning but also for applications requiring temperatures under the $0{ }^{\circ} \mathrm{C}$, such as food conservation or even freezing, which is one of the main drawbacks associated to the systems operating with the $\mathrm{H}_{2} \mathrm{O}-\mathrm{LiBr}$ mixture, since in this systems, the water, acting as refrigerant, freezes in a temperature near to $0{ }^{\circ} \mathrm{C}$.

Some of the most relevant studies related to the utilization of $\mathrm{NH}_{3}-\mathrm{LiNO}_{3}$ as the working-pair in ACS are the following: Wang et al. [30] proposed an improved absorption cycle for refrigeration applications utilizing a series of absorbers. The condenser and absorber were cooled by a water flow. The authors reported the proposed cycle was able to operate at generation temperatures from $65^{\circ} \mathrm{C}$ and produce refrigeration temperatures as low as $-40^{\circ} \mathrm{C}$. Rivera et al. [31] presented the results of an 
intermittent solar absorption refrigeration system using a cylindrical parabolic collector as the system generator. The condenser was a helical coil located inside a tank. The system was operated at generation temperatures from $75{ }^{\circ} \mathrm{C}$ to $110^{\circ} \mathrm{C}$ obtaining evaporation temperatures as low as $-11^{\circ} \mathrm{C}$. The reported system is able to produce up to $8 \mathrm{~kg}$ of ice per day. Moreno-Quintanar et al. [32] reported the operation of the same system presented by Rivera et al. [31] but utilizing the ternary mixture $\mathrm{NH}_{3}-\mathrm{LiNO}_{3}-\mathrm{H}_{2} \mathrm{O}$. The results showed the system was able to obtain values for the solar coefficient of performance by $24 \%$ higher than the achieved when the system was operated with the $\mathrm{NH}_{3}-\mathrm{LiNO}_{3}$ mixture. Moreover, with the $\mathrm{NH}_{3}-\mathrm{LiNO}_{3}-\mathrm{H}_{2} \mathrm{O}$ mixture, the lowest generation temperature required for operating the system was up to $5.5^{\circ} \mathrm{C}$ less than those required with the binary mixture. Llamas et al. [33,34] reported the results of a $10 \mathrm{~kW}$ solar absorption system for air-conditioning applications. This unit was able to deliver chilled water at temperatures near to $0{ }^{\circ} \mathrm{C}$ with thermal COP's approximated to 0.5 . On the other hand, Zamora et al. [35] reported the development of two absorption cooling prototypes. One of them used a mass flow rate of water in order to remove the condensation and absorption heat; in the second prototype, the absorber was cooled by water while the condenser was cooled by a mass flow rate of air. The authors reported the thermal coefficient of performance resulted affected by the variations in the conditions of the water flowing through the condenser, the evaporator, and the generator. Both systems were able to produce chilled water at temperatures near to $15^{\circ} \mathrm{C}$ when a mass flow rate of water was supplied to the generator at temperatures of $90^{\circ} \mathrm{C}$. The cooling capacity achieved was $12 \mathrm{~kW}$. Zamora et al. [36] presented some part-load curves for the thermal and electrical coefficients of performance reported by Zamora et al. [35]. Hernández-Magallanes et al. [37] described the evaluation of an experimental ACS. In this system, the generator and the absorber were shell and tube heat exchangers with tubes with a helical coil configuration, the rest of the components were stainless-steel plate heat exchangers. The thermal coefficients of performance varied from 0.45 to 0.7 for a cooling capacity in the range from 0.52 to $2.52 \mathrm{~kW}$. Dominguez-Inzunza et al. [38] presented the experimental assessment for a water-cooled ACS were the generator and absorber also were falling film shell and tube heat exchangers, while the condenser, evaporator and solution heat exchanger were plate heat exchangers. The operating generator temperatures were varied from $80{ }^{\circ} \mathrm{C}$ to $100{ }^{\circ} \mathrm{C}$, in the condenser the range for the temperatures variation was from $20^{\circ} \mathrm{C}$ to $34^{\circ} \mathrm{C}$. The reported cooling capacities reached up to $4.5 \mathrm{~kW}$ for evaporation temperatures as low as $4{ }^{\circ} \mathrm{C}$. The internal COP varied from 0.3 to 0.62 .

From the literature review presented, it can be seen that there are not solar systems for air-conditioning applications operating with mixtures different from the widely used $\mathrm{NH}_{3}-\mathrm{H}_{2} \mathrm{O}$ and $\mathrm{H}_{2} \mathrm{O}-\mathrm{LiBr}$. As it was stated before, the conventional mixtures have some well-known disadvantages, therefore a project titled "CEMIE-Sol" was conceived in Mexico in order to develop a solar absorption cooling system operating with the alternative working mixture ammonia/lithium nitrate, which can be used not only for air conditioning but also for refrigeration applications. In the aforementioned project, different institutions are participating, so each one is working to achieve a specific goal, such is the case of the Instituto de Energías Renovables (IER) of the Universidad Nacional Autónoma de México that is located in the state of Morelos, which goal is to develop the absorption system operating with the ammonia/lithium nitrate mixture, on the other hand, the Centro de Investigacion en Ingeniería $y$ Ciencias Aplicadas (CIICAp) from the Universidad Autónoma del Estado de Morelos, in Cuernavaca City located approximately $70 \mathrm{~km}$ south from Mexico City. The CIICAp is the responsible for developing the parabolic solar collectors to supply the required thermal energy to the absorption system. As a first step, each system has been developed and evaluated by the corresponding institutions in an independent way, and in a second step, the technologies will be coupled in order to operate a solar absorption air-conditioning system in an integrated manner. So, the present study shows the results of the developed absorption cooling system operating at controlled conditions at the IER, and the development and assessment of the parabolic-trough solar collectors, installed at the CIICAp. It is necessary to mention that the evaluation of both systems was carried out in such a way that the exit conditions of the solar collectors were, in turn, the entry conditions of the absorption system, in such 
a way that, although the systems were evaluated separately, it could be considered as if they were already integrated.

\section{System Description}

\subsection{Parabolic Trough Collector Field}

The parabolic trough collector (PTC) is able to track the sun and concentrate the solar radiation into a focal line. Each device is supported by a rigid structure, over which the aluminum parabolic profiles were assembled. The reflector is an aluminum plate, the parabolic shape is obtained because the plate rest over the profiles. The absorber is a black copper tube. The rays of the sun are reflected at the focal point where the absorber is located. A fraction of the solar radiation is transferred to a fluid, which flows inside the absorber pipe [15]. The PTC design was based on the works published by Jaramillo et al. [39] and Ibarra-Bahena et al. [40]. The material and manufacture process considered the Jaramillo's design and were installed at the CIICAp. Figure 1 shows the PTC field. The collectors' array consists of 15 parabolic trough collectors of $38.43 \mathrm{~m}^{2}$ area and divided into three rows. The tracking system was one-axis North-South direction.

Table 1 shows the design parameters of the experimental PTC with $90^{\circ}$ rim angle (see Figure 1). Experimental correlation for $\eta_{I}$ (at volumetric flow of $4 \mathrm{~L} / \mathrm{min}$ ) according to the ASRAHE 93-1986 (RA 91) standard is shown in Equation (1). The collector thermal performance was reported by Ibarra-Bahena et al. [40].

$$
\eta_{I}=0.6128-2.3025\left(\frac{\Delta T}{G_{b}}\right)
$$

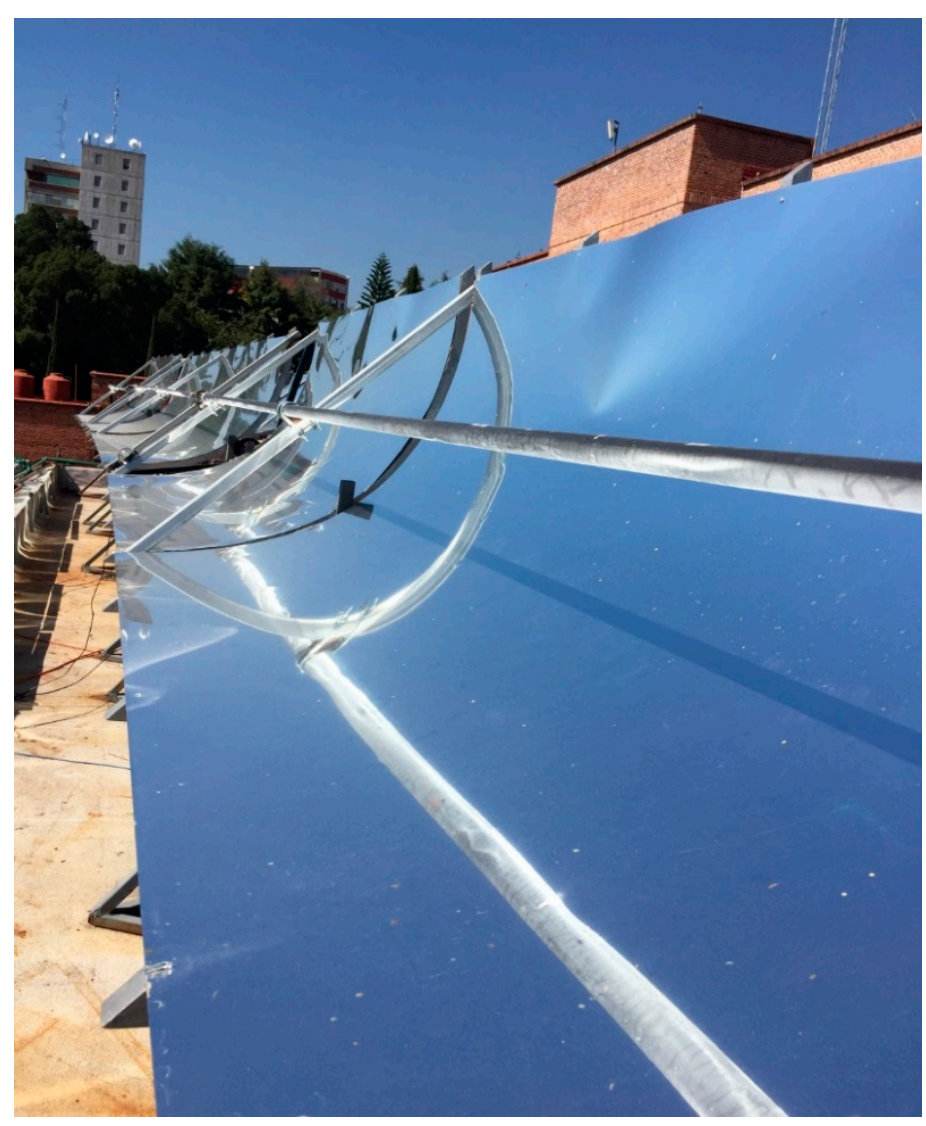

Figure 1. Photograph of parabolic trough collector during the test.

The collectors' array was connected in series and installed on the building roof, the delivery pump takes the HTF (water-ethylene 30\%) at the inlet temperature and feeds every row, the outlet 
temperature of the collectors increases according to the solar radiation. The HTF is stored inside two storage tanks with a capacity of $300 \mathrm{~L}$ in each one, the temperature increases gradually during the day. The operating conditions in the collectors' array, such as temperature, solar radiation, and mass flow rates were monitored using the instrumentation described in the next section.

Table 1. Parameters of parabolic trough collector.

\begin{tabular}{ccc}
\hline Parameter & Value & Unit \\
\hline Length & 2.44 & $\mathrm{~m}$ \\
Width & 1.05 & $\mathrm{~m}$ \\
Aperture area & 2.56 & $\mathrm{~m}^{2}$ \\
Rim angle & 90 & $\circ$ \\
Exterior diameter & 0.0254 & $\mathrm{~m}$ \\
Inner diameter & 0.019 & $\mathrm{~m}$ \\
Focal length & 0.26 & $\mathrm{~m}$ \\
Number of PTC & 15 & \\
Orientation & \multicolumn{2}{c}{ North-South } \\
\hline
\end{tabular}

Table 2 shows the optical parameters measured and calculated for the PTC designed.

Table 2. Optical parameters for the Parabolic Trough Collector (PTC).

\begin{tabular}{cc}
\hline Parameter & Value \\
\hline Concentration ratio C & 13.158 \\
Reflectivity $\rho$ & 0.92 \\
Transmisivityn $\tau$ & 1.0 \\
Abpsortance $a s$ & 0.9 \\
Intercept factor $\gamma$ & 0.84 \\
Geometric factor $A_{f}$ & 0.22 \\
Optical efficiency $\eta_{o}$ & 0.705 \\
\hline
\end{tabular}

Instrumentation of PTC

The temperature was measured by a set of thermocouples type " $\mathrm{T}$ "; to register the data of solar irradiance it was utilized a couple of Licor pyranometers series PY101122 and PY106225. The mass flow rate was registered using a propeller flowmeter. An HP data acquisition system using the software Agilent VEE Pro 9.2 was utilized in order to process the outlet signals from the different sensors.

\subsection{Experimental Setup for the Absorption Cooling System}

The absorption cooling unit operated with the ammonia-lithium nitrate mixture and was built using five plate heat exchangers (PHE) as a generator, absorber, condenser, evaporator, and economizer, the system also utilized a solution pump, an expansion valve, and two low-capacity storage tanks. The PHE had a vertical orientation. The experimental absorption cooling system was conceived in several stages: the first one involves the development of a first-law thermodynamic model that included mass, matter and thermal balances as well as equations for the thermophysical properties for the ammonia-lithium nitrate mixture. During the second stage, the type of plate heat exchangers to use was defined, considering the affinity between the components commercially available and the desired characteristics for the heat exchangers, for instance, the maximum permissible dimensions and the heat load to be transferred as well as the properties of the working mixture. In the last stage, it was utilized a computational code to obtain the theoretical heat transfer area for each component of the ACS, this code employs the main geometric characteristics of the selected plate heat exchangers.

The plate heat exchangers utilized were manufactured by Alfa Laval ${ }^{\mathrm{TM}}$. The model Alfanova $52^{\circledR}$ was used in the components acting as generator, economizer, and absorber, the number of plates in these components was 40 . The condenser and evaporator utilized the model Alfanova $27^{\circledR}$ with 
20 plates in each heat exchanger. A Milton Roy ${ }^{\circledR}$ diaphragm pump was used to send the solution from the absorber to the generator. The expansion valve used was a stainless steel needle valve with a maximum flow coefficient equal to 0.004 . A couple of small capacity ( $2 \mathrm{~L}$ ) storage tanks were included in the system. One of them was installed in the line at the exit of the generator, whose porpoise was to allow the phase separation, facilitating the ammonia vapor to flow to the condenser, and the solution liquid-phase to flow to the absorber. The other tank was useful to keep the liquid solution at an adequate level, in order to avoid the undesirable flow of the solution to the evaporator. The ACS measurements are $1 \times 1 \times 0.8 \mathrm{~m}$ (width-height-depth), resulting in a system with an overall volume of around $0.7 \mathrm{~m}^{3}$. All of the components in the system (including the piping and valves) are made out of stainless steel to avoid corrosion problems caused by ammonia.

The thermal energy required to desorb the refrigerant from the solution in the generator, before the integration of the solar system was supplied by an auxiliary heating system whose function is to simulate the heat power that would be supplied by the parabolic trough collector field. This auxiliary system uses an electric resistance to heat a mass flow rate of water and keep its temperature at the desired conditions. The hot water is supplied to the generator at a gauge pressure near to $200 \mathrm{kPa}$ ( 2 bar), avoiding the boiling of the water inside the heating system. Moreover, two additional auxiliary systems were used during the experimental assessment for the ACS: one of them was used to remove the heat delivered from the absorption and condensation processes; the last auxiliary system is used for supplying a mass flow rate of water that is going to be chilled in the evaporator. The system was designed to provide a mass flow rate of water to the evaporator at a constant temperature.

Instrumentation of the Absorption Cooling System

In order to assess the ACS performance, a complete set of different sensors was installed on the main components of the absorption system. The pressure was registered in the inlet ports of the solution and refrigerant, in the main components (generator, condenser, evaporator, and absorber), with that porpoise, Ashcroft ${ }^{\circledR}$ piezoelectric transducers were utilized. To measure the mass flow rate of refrigerant and diluted solution, a couple Micro Motion ${ }^{\circledR}$ Elite Coriolis flowmeters were used. The concentrated solution was registered by utilizing an Omega ${ }^{\circledR}$ rotameter; the mass flow rates of water in the three auxiliary systems were obtained by the use of turbine flow meters. The temperatures were measured in each inlet and outlet port of every plate heat exchanger, with the use of PT1000 resistance temperature detectors (RTD). The uncertainties related to each measuring unit utilized during the assessment of the ACS is presented in Table 3.

Table 3. Uncertainties reported by the instruments' manufacturers.

\begin{tabular}{cc}
\hline Measuring Instrument & Uncertainty \\
\hline Elite Coriolis flowmeter & $\pm 0.10 \%$ \\
Omega rotameter & $\pm 1 \%$ \\
Turbine flowmeter & $\pm 1 \%$ \\
Pressure transducer & $\pm 1 \%$ \\
RTD & $\pm 0.3{ }^{\circ} \mathrm{C}$ \\
\hline
\end{tabular}

A schematic diagram of the ACS showing the different internal and external streams is presented in Figure 2. 


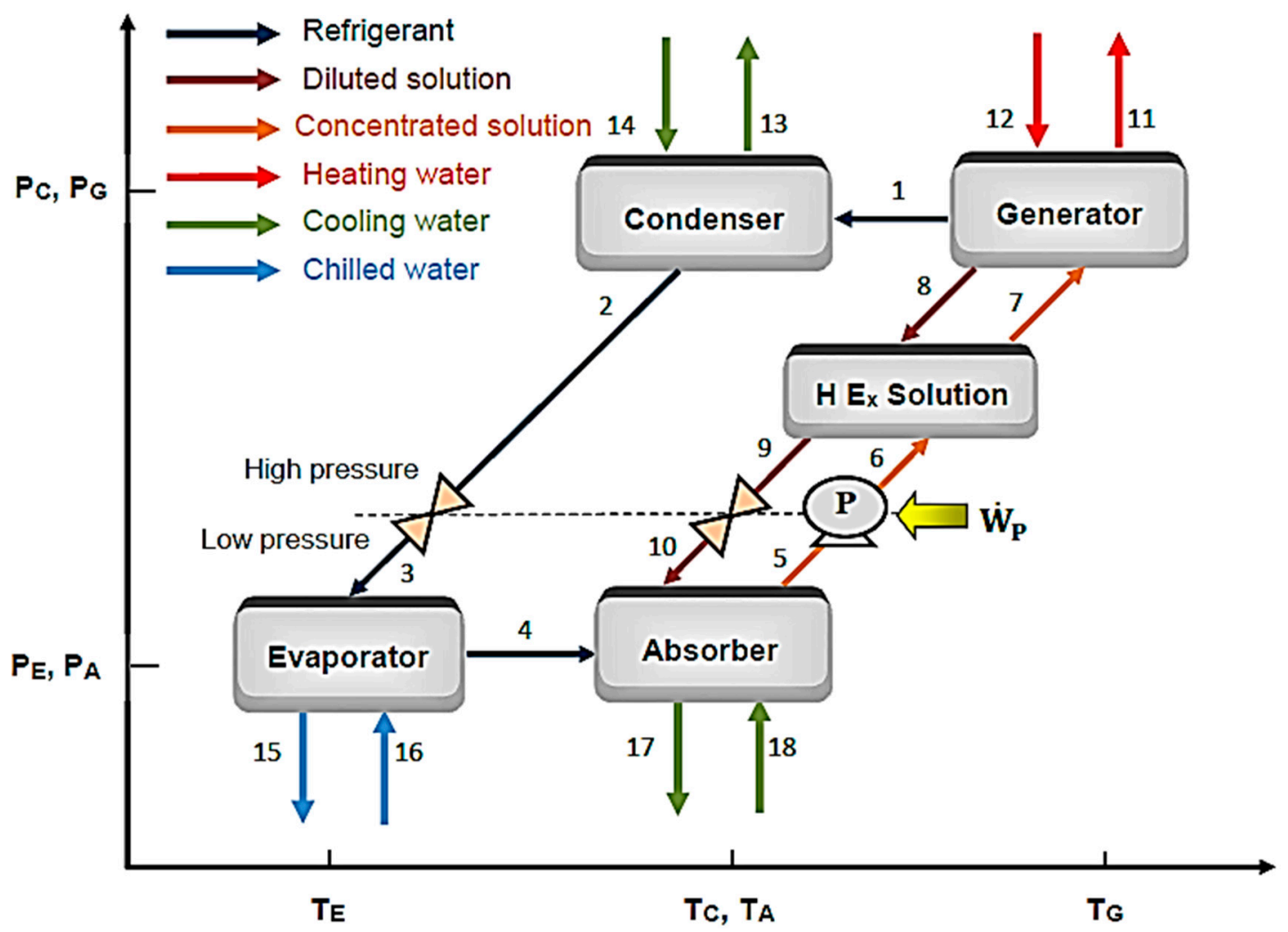

Figure 2. Schematic diagram showing the main components of an absorption system with rectifier and heat exchanger for the solution streams.

\subsection{Operation of the Absorption Cooling System}

The heating water, coming from the solar system, is circulated through the desorber to separate the refrigerant from the concentrated solution. At the exit of the generator, there is a two-phase flow. The vapor-phase in this flow consists of the ammonia vapor, the liquid-phase is an ammonia-lithium nitrate mixture with a low concentration of ammonia. The two-phase flow exits the generator and enters to one of the small capacity tanks, there, the phase separation is carried out.

The ammonia vapor flows to the condenser where it is liquefied by means of the cooling water supplied by the auxiliary cooling system. Once the ammonia has been condensed, it flows through the expansion valve. As a consequence of the expansion process, the ammonia pressure and temperature are reduced in such a way that the corresponding thermodynamic state for the ammonia is a saturated liquid-vapor mixture. In this point, the ammonia is at the lowest temperature of the cycle, having the maximum cooling potential. At these conditions, the ammonia enters the evaporator to produce the desired cooling effect, taking a heat load from the auxiliary fluid (water) circulating in the opposite side of the evaporator. As a result of the heat transfer, the ammonia thermodynamic state is changed from a saturated liquid-vapor mixture to a superheated vapor. The ammonia vapor leaves the evaporator and is mixed with the diluted solution coming from the generator, the mixture process takes place before the diluted solution enters the absorber. The refrigerant-absorbent mixture provokes an exothermic reaction, so the heat released in this process is transferred from the solution to the stream flowing in the adjacent channels of the plate heat exchanger acting as the absorber. As a result of the absorption process, a mass flow rate of concentrated solution exits the absorber and is pumped to the generator, in order to start the cycle again.

An additional heat exchanger called "solution heat exchanger" or "economizer" is included in the absorption cycle to exchange heat between the streams flowing in and out of the generator, the use of the economizer augments the coefficient of performance (COP) by reducing the heat released in the absorber and the heat supplied to the generator. Figure 3 shows the absorption cooling system. 


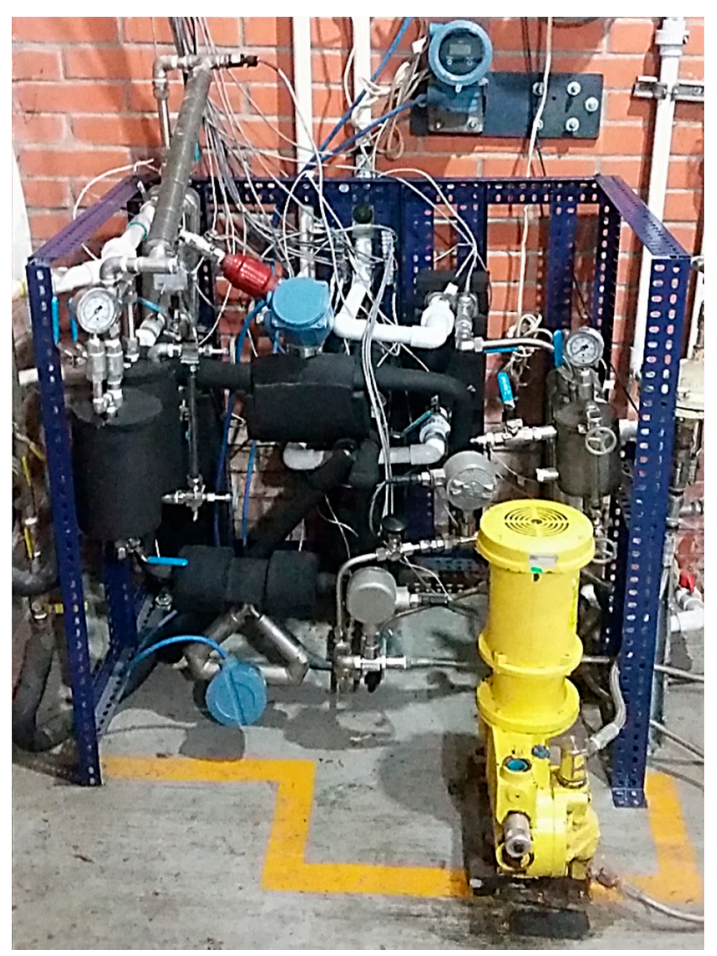

Figure 3. Developed absorption cooling machine.

\subsection{Experimentation Design for the Absorption Cooling System}

To describe the design of the experimentation considered for the evaluation of the proposed absorption system, it is necessary to identify the main parameters of the system into two primary groups: input and output parameters. Input parameters are those that depend on the external conditions of the absorption equipment and are independent of other system parameters; on the contrary, output parameters are derived from the former and they cannot be fixed directly. Some input parameters are the external temperatures of the water to be chilled $\left(T_{e, w i}\right)$, the condenser and absorber's cooling water $\left(T_{c, w i}, T_{a, w i}\right)$, and the heating water $\left(T_{g, w i}\right)$, other input parameters are the aperture of the expansion valve, the external mass flow rates of water, the mass flow rate of concentrated solution $\left(\dot{m}_{\text {conc }}\right)$ that is driven by the internal pump, and the initial concentration of the mixture $(X)$. The output parameters are: the pressures of the system, the mass flow rate of ammonia desorbed $\left(\dot{m}_{r e f}\right)$, the thermal powers in the components, the COP and the flow ratio.

A test consisted in maintaining constants the input parameters while the output parameters are monitored, for a defined period of time. During the evaluation of the cooling system it was shown that once a steady-state was achieved, the same results were obtained if a test lasted between 10 and $60 \mathrm{~min}$, so for convenience, it was decided to perform the assessment of the system with duration of $20 \mathrm{~min}$ for each steady-state. Once the test was over, one of the input parameters was changed and the procedure was repeated, in such a way that a series of tests were obtained. Then, it was possible to evaluate the effect of the change in a single parameter on the system performance.

The input parameters considered to carry out the experimental assessment of the system are shown in Table 4. 
Table 4. Input parameters values during the assessment of the system.

\begin{tabular}{cc}
\hline Input Parameter & Value \\
\hline Condensation/absorption water temperature & $20-28{ }^{\circ} \mathrm{C}$ \\
Generation water temperature & $85-105^{\circ} \mathrm{C}$ \\
Evaporation water temperature & $20^{\circ} \mathrm{C}$ \\
Mass flow rate of condensation/absorption water & $12 \mathrm{~kg} / \mathrm{min}$ \\
The mass flow rate of generation water & $16 \mathrm{~kg} / \mathrm{min}$ \\
The mass flow rate of evaporation water & $10 \mathrm{~kg} / \mathrm{min}$ \\
Expansion valve's aperture & $10 \mathrm{turns}$ \\
Strong solution mass flow rate & $0.8 \mathrm{~kg} / \mathrm{min}$ \\
The initial concentration of the mixture & $54 \%$ (refrigerant mass ratio) \\
\hline
\end{tabular}

\section{Important Parameters}

\subsection{Parabolic Trough Collector}

The thermal efficiency of the PTC is measured considering a normal incidence angle. However, its efficiency is affected when $\theta>0$. According to Rabl. [41] for the PTC, the thermodynamics first-law efficiency, can be expressed as:

$$
\eta_{I}=F_{R}\left(\eta_{0} K_{\theta}-\frac{U_{L}}{C} \cdot \frac{\left(T_{i}-T_{a}\right)}{G_{B}}\right)
$$

where $K_{\theta}$ is the incidence angle modifier that includes the spilling of radiation over the end of a finite PTC.

Equation (3) shows the regression curve of $K_{\theta}$ based on experimental data:

$$
K_{\theta}=1.0041+0.0003 \theta-0.0002 \theta^{2}+9 \times 10^{-19} \theta^{3}
$$

Performance data for a single collector cannot be applied directly to a series of interconnected collectors. But, it is necessary to consider the thermal losses in the pipelines that interconnect the collectors and the heat exchanger that is used during the system's operation. Jaramillo et al. [42] describe a methodology to calculate the useful heat for an array composed by identical collectors. This methodology was conveniently adopted in the present work and it is described, as follows:

The useful energy output from an array of $N$ identical solar collectors operated in series can be calculated using

$$
Q_{u, N}=F_{R \varepsilon}\left[\frac{1-(1-K)^{N}}{K}\right]\left[\eta_{0}^{\prime} K_{\theta} A_{a} G_{B}-U_{L}^{\prime} A_{r}\left(T_{s}-T_{a}\right)\right]^{+}
$$

where $F_{R \varepsilon}$ is the modified heat removal factor and it is calculated as:

$$
F_{R \varepsilon}=\frac{F_{R}}{1+K\left[\frac{\left(\dot{m} C_{p}\right)_{c}}{\varepsilon_{c}\left(\dot{m} C_{p}\right)_{\min }}-1\right]}
$$

In Equation (5) $\varepsilon_{c}$ is the effectiveness of the heat exchanger, $\left(\dot{m} C_{p}\right)_{c}$ is the collector side capacitance, $\left(\dot{m} C_{p}\right)_{\min }$ is the lowest value for all the thermal capacitance rates of the working fluid in the heat exchanger on the collector side, and $K$ is defined by Jaramillo et al. [42], as:

$$
K=\frac{A_{r} F_{R} U_{L}^{\prime}}{\left(\dot{m} C_{p}\right)_{c}}
$$


The modified optical efficiency and global thermal losses coefficient are given by Equations (7) and (8), respectively:

$$
\begin{gathered}
\eta_{0}^{\prime}=\frac{\eta_{0}}{1+\frac{(U A)_{\text {pipe }}}{\left(\dot{m} C_{p}\right)_{c}}} \\
U_{L}^{\prime}=\left(\frac{1-\frac{(U A)_{\text {pipe }}}{\left(\dot{m} C_{p}\right)_{c}}+\frac{2(U A)_{p i p e}}{A_{r} U_{L} F_{R}}}{1+\frac{(U A)_{\text {pipe }}}{\left(\dot{m} C_{p}\right)_{c}}}\right)
\end{gathered}
$$

Disregarding the heat loss from the pipeline between the heat exchanger and the storage tank, according to Jaramillo et al. [42] Equation (3) can be rewritten as indicated by Equation (9).

$$
Q_{u, N}=0.87496\left[\frac{1-\left(1-3.02 \times 10^{-3}\right)^{N}}{3.02 \times 10^{-3}}\right]\left[1.79189 K_{\theta} G_{B}-13.67\left(T_{s}-T_{a}\right)\right]^{+}
$$

The thermal efficiency $\left(\eta_{\text {Ther }}\right)$ for the PTC is defined as the ratio of the useful heat $\left(Q_{u}\right)$ gained by the heat transfer fluid, to the solar energy intercepted by the collector aperture area $\left(S_{a}\right)$. The thermal efficiency is determined, as follows:

$$
\eta_{\text {Ther }}=\frac{Q_{u}}{S_{a}}=\frac{\dot{m} C_{p}\left(T_{\text {out }}-T_{\text {in }}\right)}{G_{b} A_{a}}
$$

where $\dot{m}$ is the mass flow rate of the HTF, $C_{p}$ is the specific heat at constant pressure of the HTF, Tout is the outlet fluid temperature, Tin is the inlet fluid temperature, $G_{b}$ is the beam radiation, and $A_{a}$ is the collector aperture area.

\subsection{Absorption Cooling System}

The mathematical model for determining the thermal powers to be transferred in the main components of the absorption cooling system, was a first-law thermodynamic model, which was based on the Equations (11) to (30) (see Figure 2 for a subscripts reference).

$$
\begin{gathered}
T_{1}=T_{12}-10{ }^{\circ} \mathrm{C}=T_{8} \\
T_{2}=T_{14}+10{ }^{\circ} \mathrm{C} \\
P_{2}=P_{\text {sat@T } 2}=P_{6}=P_{7}=P_{8}=P_{9}=P_{1} \\
T_{4}=T_{15}-10{ }^{\circ} \mathrm{C} \\
P_{4}=P_{\text {sat@T }}=P_{5}=P_{10}=P_{3} \\
T_{5}=T_{18}+10{ }^{\circ} \mathrm{C} \\
X_{5}=f\left(T_{5}, P_{5}\right) \\
h_{5}=h_{f @ T 5} \text { y P5 } \\
v_{5}=v_{f @ T 5} \text { y P5 } \\
\dot{W}_{p}=v_{5}\left(P_{6}=P_{5}\right) \\
h_{6}=h_{5}+\dot{W}_{p} \\
h_{8}=h_{f @ T 8 y P 8} \\
X_{8}=f\left(T_{8}, P_{8}\right)
\end{gathered}
$$




$$
\begin{gathered}
h_{7}=\varepsilon\left(h_{8}-h_{6}\right)+h_{6} \\
\dot{m}_{1}=\frac{\dot{m}_{e, e x t}}{h_{4}-h_{3}} \\
\dot{m}_{8}=\dot{m}_{1} \frac{1-X_{4}}{X_{5}-X_{8}}=\dot{m}_{9}=\dot{m}_{10} \\
\dot{m}_{5}=\dot{m}_{1}+\dot{m}_{8} \\
\dot{Q}_{g}=\dot{m}_{1} h_{1}+\dot{m}_{10} h_{8}+\dot{m}_{5} h_{7} \\
\dot{Q}_{c}=\dot{m}_{1}\left(h_{2}-h_{1}\right) \\
\dot{Q}_{a}=\dot{m}_{1} h_{4}+\dot{m}_{10} h_{10}+\dot{m}_{5} h_{5}
\end{gathered}
$$

The external coefficient of performance $\left(C O P_{\text {ext }}\right)$ for the absorption cooling system can be determined using Equation (31):

$$
C O P_{e x t}=\frac{\dot{Q}_{e, e x t}}{\dot{Q}_{g, e x t}+\sum \dot{W}_{p, e x t}}
$$

In Equation (31), $\dot{Q}_{e, e x t}$ represents the cooling power transferred from the water flowing in the evaporator and it is determined, as it is established by Equation (32).

$$
\dot{Q}_{e, e x t}=\dot{m}_{e, w} C_{p}\left(T_{16}-T_{15}\right)
$$

$\dot{Q}_{g, e x t}$ is the thermal power supplied by the heating water in the generator and is calculated, as Equation (33) indicates.

$$
\dot{Q}_{g, e x t}=\dot{m}_{g, w} C_{p}\left(T_{12}-T_{11}\right)
$$

Finally, the term $\sum \dot{W}_{p, e x t}$ involves the power required to operate the pumps in each external system, such as the solar or the auxiliary heating system, auxiliary cooling system, and the system of the water to be chilled. This term is determined considering three different types of pressure drop inside the plate heat exchangers: friction $\left(\Delta P_{f}\right)$, gravity $\left(\Delta P_{\text {grav }}\right)$, and flow distribution in the PHE channels $\left(\Delta P_{N}\right)$. These terms are calculated, as shown below.

$$
\sum \dot{W}_{p, e x t}=\Delta P_{f}+\Delta P_{\text {grav }}+\Delta P_{N i}
$$

where:

$$
\begin{gathered}
\Delta P_{f}=2 f\left(\frac{L}{d_{h}}\right)\left(\frac{G^{2}}{\rho}\right) \\
\Delta P_{\text {grav }}=\rho g L \\
\Delta P_{N}=1.5\left(\frac{\rho U^{2}}{2}\right) N
\end{gathered}
$$

An important criterion in the assessment of any ACS is the "flow ratio" (FR) which is a dimensionless measure of the rate of refrigerant produced relative to the mass flow rate of concentrated solution pumped from the absorber to the generator, this parameter is determined as indicated by Equation (38).

$$
F R=\frac{\dot{m}_{5}}{\dot{m}_{1}}
$$


The exergy efficiency for the absorption cooling system was determined from the Equation (39):

$$
\eta_{e x}=\frac{\dot{X}_{e}}{\dot{X}_{g}+\sum \dot{W}_{p, e x t}}
$$

The exergy rates in the evaporator $\dot{X}_{e}$ and generator $\dot{X}_{g}$ are determined from a general balance of exergy applied to the mass flow rates of water in both components. The general balance of exergy in steady-state conditions, disregarding the changes of potential and kinetic exergies, as well as mechanical work interactions, is presented in Equation (40).

$$
\dot{X}=\sum \dot{m}_{\text {in }}\left[\left(h-h_{0}\right)-T_{0}\left(s-s_{0}\right)\right]_{\text {in }}-\sum \dot{m}_{\text {out }}\left[\left(h-h_{0}\right)-T_{0}\left(s-s_{0}\right)\right]_{\text {out }}+\dot{Q}\left(1-\frac{T_{0}}{T}\right)-I
$$

The term I in Equation (40) is the irreversibility, and it is calculated, as is indicated by Equation (41):

$$
I=T_{0} S_{g e n}
$$

where $S_{\text {gen }}$ represents the entropy generated during the heat transfer process, and can be obtained from an entropy balance applied to the system of interest. A general entropy balance for a control volume in steady-state conditions is shown in Equation (42).

$$
\dot{m}_{\text {in }} s_{\text {in }}-\dot{m}_{\text {out }} s_{\text {out }}+\frac{\dot{Q}}{T_{0}}+S_{\text {gen }}=0
$$

when Equations (41) and (42) are applied to the mass flow rate of water in the evaporator, $\dot{X}_{e}$ results to be, as indicated in Equation (43):

$$
\dot{X}_{e}=\dot{Q}_{e, e x t}\left(1-\frac{T_{0}}{T_{e, w i}}\right)
$$

The exergy rate for the mass flow rate of heating water in the generator $\dot{X}_{g}$, can be determined by Equation (44):

$$
\dot{X}_{g}=\dot{Q}_{g, e x t}\left(1-\frac{T_{0}}{T_{g, w i}}\right)
$$

On the other hand, for the PTC exergy analysis, according to MacPhee and Dincer [43], the receiver tube exergy rate transfer to HTF with a reference to environment is defined as:

$$
E X_{u}=\dot{m} C_{p, f}\left[\left(T_{\text {out }}-T_{\text {in }}\right)-T_{\text {amb }} \ln \left(\frac{T_{\text {out }}}{T_{\text {in }}}\right)\right]
$$

Assuming the sun as an infinite thermal source, Petela [44] reported the maximum efficiency ratio for determining an exergy of thermal emission at temperature T. In Equation (46), $E X_{a}$ is the solar radiation exergy absorbed by the system.

$$
E X_{a}=A_{a p} I_{D}\left[1+\frac{1}{3}\left(\frac{T_{a m b}}{T_{s}}\right)^{4}-\frac{4 T_{a m b}}{3 T_{s}}\right]
$$

$T_{s}$ is considered as $5762 \mathrm{~K}$ according to Dutta [45], because is the apparent sun temperature. The exergy efficiency is defined as indicated by Equation (47) Chafie et al. [46].

$$
\eta_{\text {Exer }}=\frac{E X_{u}}{E X_{a}}=\frac{\dot{m} C_{p, f}\left[\left(T_{\text {out }}-T_{\text {in }}\right)-T_{\text {amb }} \ln \left(\frac{T_{\text {out }}}{T_{\text {in }}}\right)\right]}{A_{a p} I_{D}\left[1+\frac{1}{3}\left(\frac{T_{a m b}}{T_{s}}\right)^{4}-\frac{4 T_{\text {amb }}}{3 T_{s}}\right]}
$$


For the combined system, integrated by the PTC and the absorption cooling system, the solar coefficient of performance and the exergy efficiency can be calculated as it is indicated by Equations (48) and (49).

$$
\begin{gathered}
\mathrm{COP}_{\text {solar }}=\frac{\dot{Q}_{e, e x t}}{S_{a}} \\
\eta_{\text {system }}=\frac{\dot{Q}_{e, e x t}\left(1-\frac{T_{0}}{T_{e, w i}}\right)}{A_{a p} I_{D}\left[1+\frac{1}{3}\left(\frac{T_{a m b}}{T_{s}}\right)^{4}-\frac{4 T_{a m b}}{3 T_{s}}\right]}
\end{gathered}
$$

\section{Results}

In this section, the experimental data obtained for both: the parabolic trough collector field and the absorption cooling system are presented. As it was mentioned before, this investigation proposes the coupling between these independent systems. The coupling is proposed to be through a storage tank, where the thermal energy gained in the solar field becomes available to be supplied to the generator in the absorption cooling system. Using a storage tank involves one major advantage: (although there is temperature stratification in the storage tank,) after the transient heating process where the fluid average temperature is increasing, there is a process where the maximum fluid temperature is achieved and it remains almost constant for at least two hours (see see Figures 4, 6, 8 and 10). So, it is possible to supply the heating fluid at a constant temperature to the generator in the absorption cooling system.

In order to simulate the conditions of the heating fluid that would be achieved with the solar system, for the results presented in this section, it was used the auxiliary heating system described in Section 2.2, which supplies the heating fluid to the generator at constant temperature. Several tests for different generation temperatures that are easily achieved with the solar system were performed with the absorption cooling system.

Figure 4 shows the temperature profiles of the storage tank, inlet, and outlet temperature as a function of solar irradiance $\left(G_{b}\right)$ corresponding to November 24 . The test was considered for an office schedule from 10:00 a.m. to 16:00 p.m., the solar radiation showed a Gaussian profile, this day the maximum $G_{b}$ was $856 \mathrm{~W} / \mathrm{m}^{2}$ in Cuernavaca city. In the storage tank profile, it is possible to identify three sections: the transitory section from 9:30 a.m. to 12:00 p.m., the stable section from 12:00 p.m. to 14:00 p.m., and the cooling section from 14:00 p.m. to 16:00 p.m. The temperature profiles increased as the solar irradiance increased, however, the $G_{b}$ decreased after the 12:00 p.m. The behavior of the storage tank temperature profile was kept constant for two hours. The average temperature held in the storage tank was $97.2^{\circ} \mathrm{C}$, the maximum outlet temperature HTF was $103.3^{\circ} \mathrm{C}$.

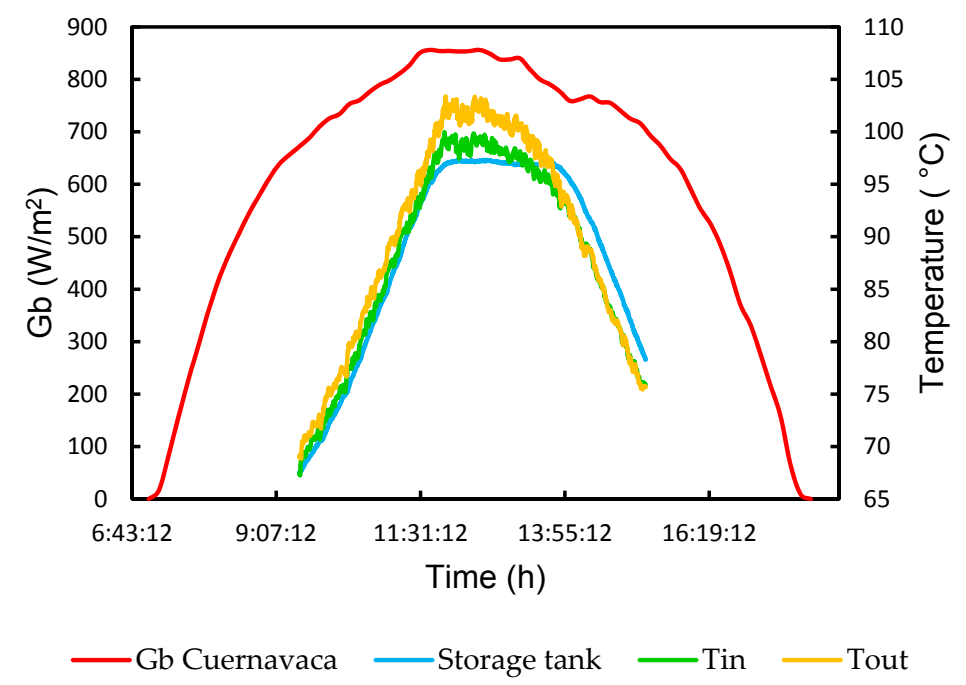

Figure 4. Behavior $G_{b}$ and outlet, inlet, and storage tank temperatures, 24 November 2017. 
The thermal efficiency and the useful heat were calculated during the stable section, these behaviors were shown in Figure 5. This plot shows the behavior of several parameters every $10 \mathrm{~min}$. The maximum value calculated for thermal efficiency was $19.8 \%$ and the minimum $9.8 \%$. The useful heat was determined considering $38.43 \mathrm{~m}^{2}$ as the total collector's area and $G_{b}$ in a range from 759 to $854 \mathrm{~W} / \mathrm{m}^{2}$. The results show the useful heat can reach $6.5 \mathrm{~kW}$ as maximum and $3 \mathrm{~kW}$ as a minimum. The behavior of $\mathrm{Qu}$ is not constant due to the $G_{b}$ variation during the test. The exergy efficiency follows the same trend than others parameters varying from 7 to $14.2 \%$.

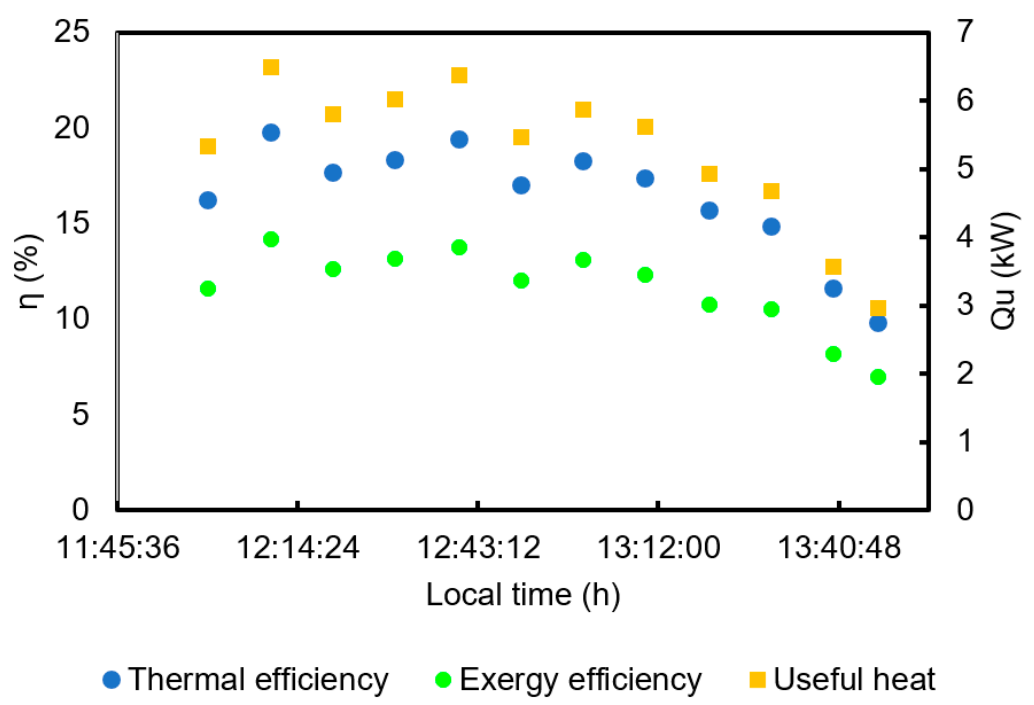

Figure 5. Thermal efficiency, exergy efficiency, and useful heat behavior, 24 November 2017.

The test of corresponding of 29 November is presented in Figure 6. It shows the profiles of inlet, outlet, and storage tank temperatures during the day in Cuernavaca city. The solar radiation showed a Gaussian profile, the maximum $G_{b}$ was $835 \mathrm{~W} / \mathrm{m}^{2}$, after the $12: 10$ p.m. a few clouds showed up. The temperature profiles for the variables Tin and Tout, diminished when the clouds appeared. The evaluation was realized for $6 \mathrm{~h}$ (9:30 a.m.-15:30 p.m.). In this plot is possible to identify three sections also, the stable section was in a range from 11:39 a.m. to 14:39 p.m. During this section, the average storage tank temperature was $96.93{ }^{\circ} \mathrm{C}$ and the maximum outlet temperature of HTF was $102.72{ }^{\circ} \mathrm{C}$.

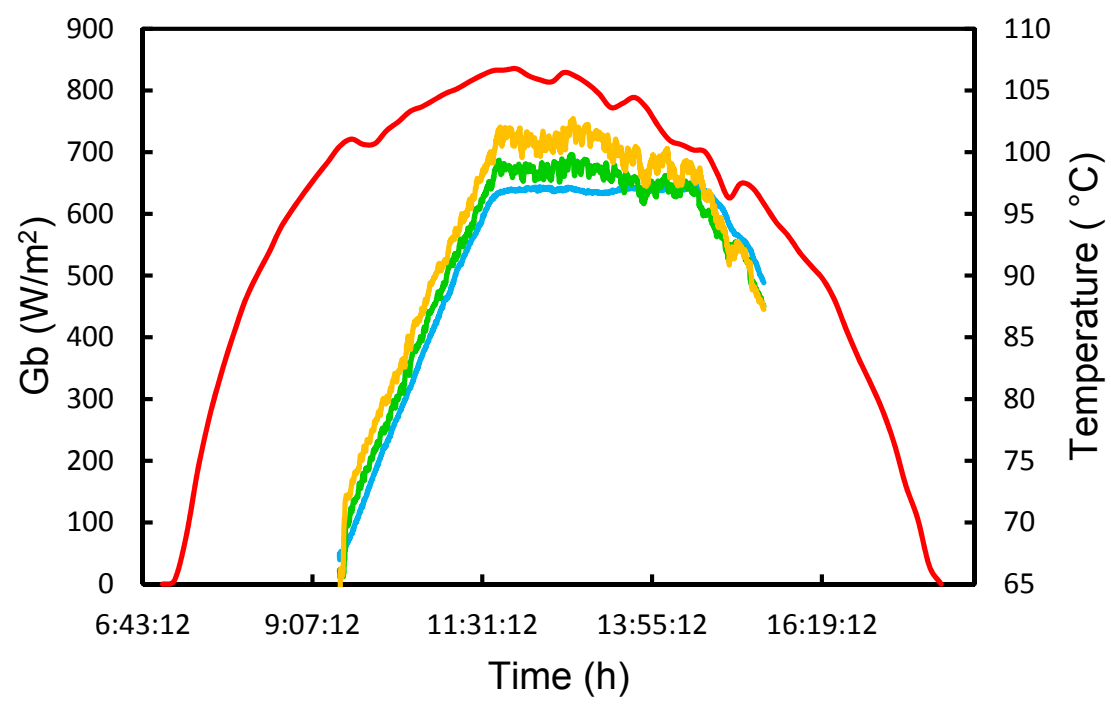

-Gb Cuernavaca - Storage tank Tin Tout

Figure 6. Behavior $G_{b}$ and outlet, inlet and storage tank temperatures, 29 November 2017. 
The analysis of thermal efficiency and useful heat is presented in Figure 7. It shows the behavior of thermal efficiency for the stable section, for which the maximum value calculated was $16.95 \%$, this value is the average efficiency for a $10 \mathrm{~min}$ period. The useful heat behavior varied from $2.9 \mathrm{~kW}$ to $5.2 \mathrm{~kW}$, the $G_{b}$ was registered between $700.1 \mathrm{~W} / \mathrm{m}^{2}$ to $832 \mathrm{~W} / \mathrm{m}^{2}$. In this case, the exergy efficiency varied between 7.4 and 11.7.

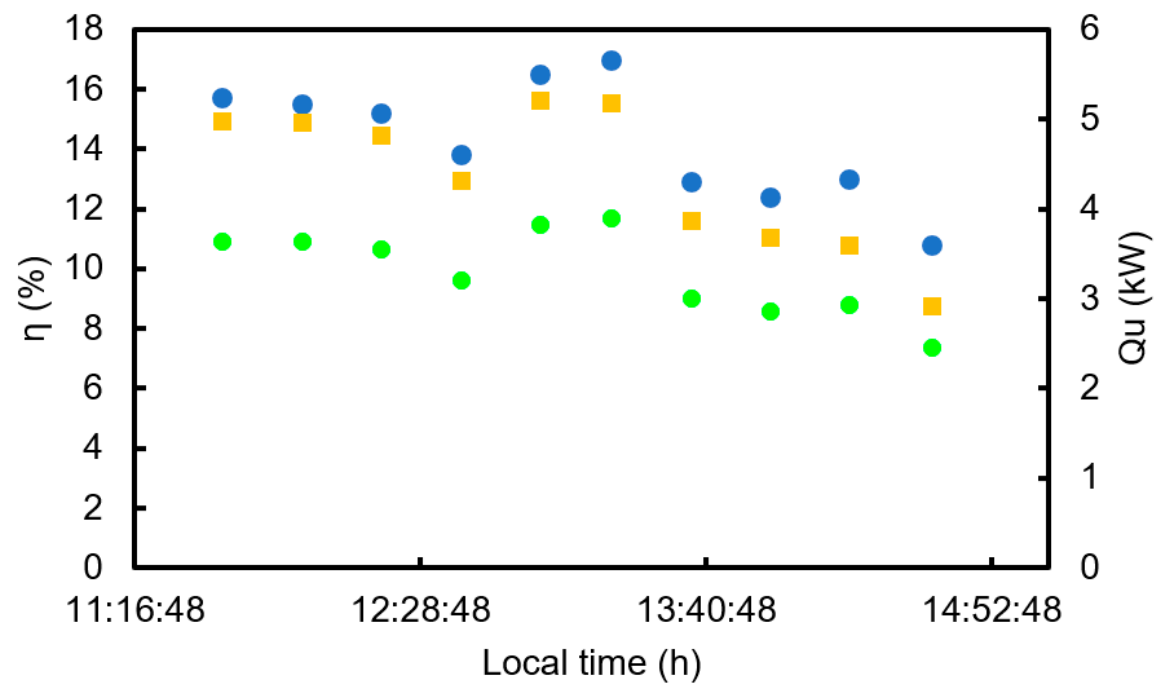

\section{- Thermal efficiency • Exergy efficiency Useful heat}

Figure 7. Thermal efficiency, exergy efficiency, and useful heat, 29 November 2017.

Figure 8 shows the temperature profiles in the storage tank, and at the inlet and outlet from the solar collector's field as a function of the solar irradiance $(\mathrm{Gb})$ registered in Cuernavaca in 5 December. The solar radiation presents a normal profile; however, some clouds appeared during the day as it can be seen in the plot, the maximum $G_{b}$ was $859 \mathrm{~W} / \mathrm{m}^{2}$. The period of evaluation was considered from 9:30 a.m. to 15:00 p.m. For this day the stable section was in a range from 12:00 p.m. to 14:00 p.m. The behavior of the storage tank temperature profile was held constant for two hours. The average temperature held in the storage tank was $96.8^{\circ} \mathrm{C}$, the maximum outlet temperature $\mathrm{HTF}$ was $101.7^{\circ} \mathrm{C}$.

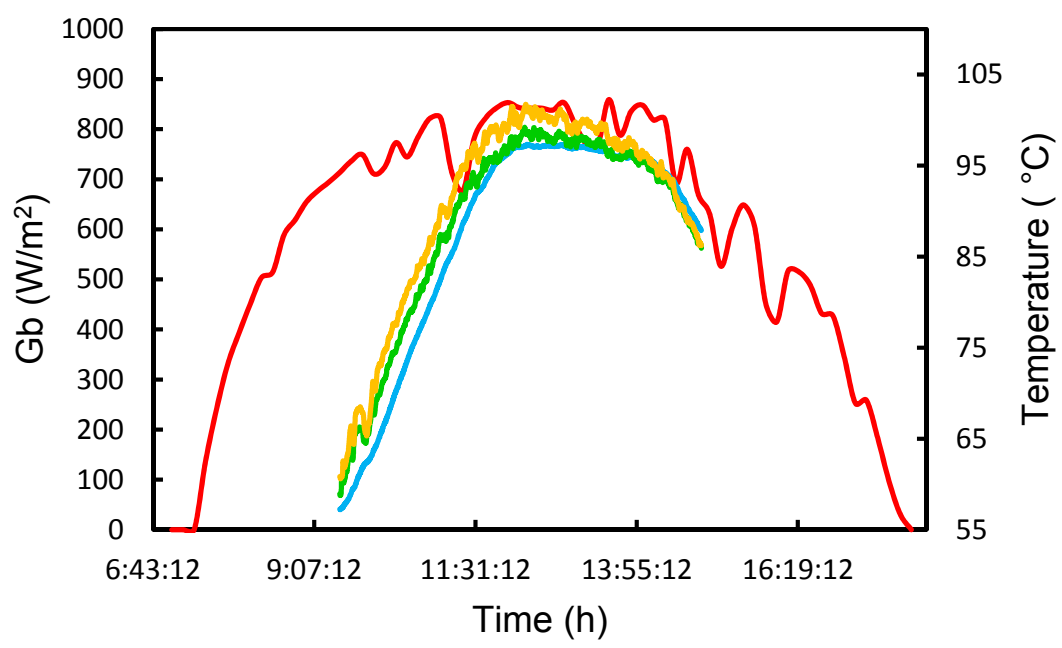

- Gb Cuernavaca - Storage tank Tin Tout

Figure 8. Behavior $G_{b}$ and outlet, inlet and storage tank temperatures, 5 December 2017. 
The thermal efficiency and useful heat were analyzed for the stable section and are presented in Figure 9. In this day the values of efficiency were lower than other tests, the $G_{b}$ was registered in a range from 668.6 to $853 \mathrm{~W} / \mathrm{m}^{2}$, as a result of a cloudy day, the maximum value calculated was $14.82 \%$ and the minimum was $6.27 \%$. The data was average of efficiency every $10 \mathrm{~min}$. However, the useful heat was between 1.9 to $4.9 \mathrm{~kW}$ when the $G_{b}$ was around $853 \mathrm{~W} / \mathrm{m}^{2}$. The minimum exergy efficiency was around 4.2 at 14:00 while the maximum value was 11.1 at 12:09.

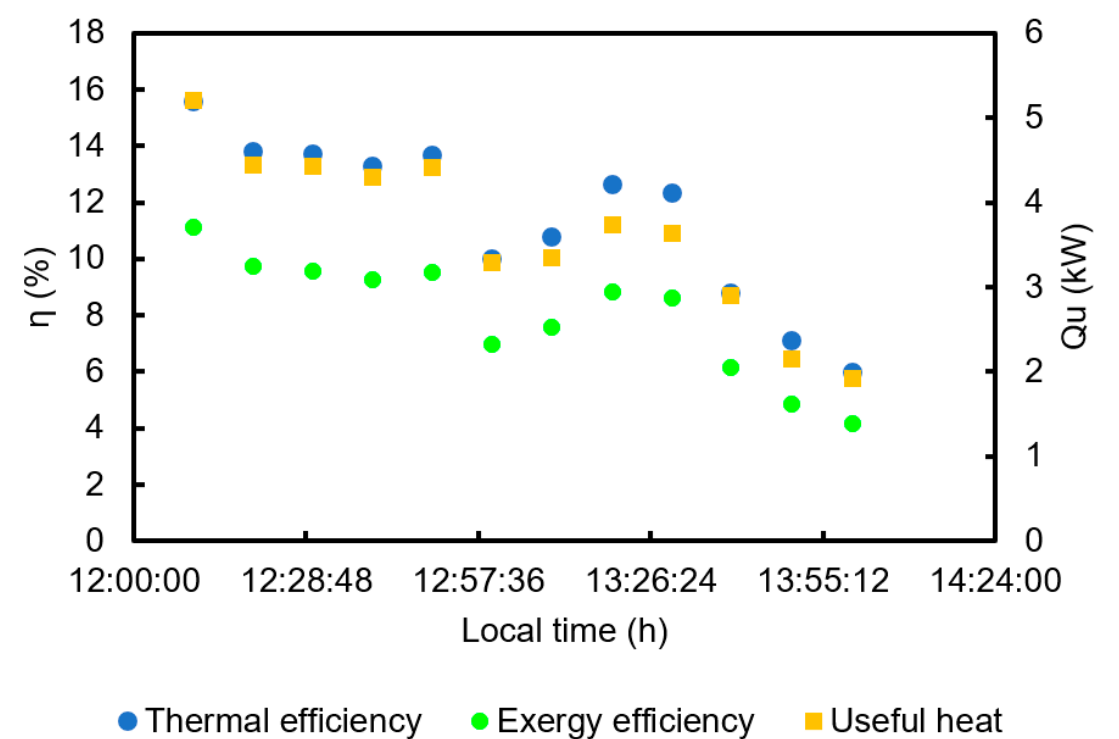

Figure 9. Thermal efficiency, exergy efficiency, and useful heat, 5 December 2017.

The Figure 10, corresponding to 11 December, shows the solar radiation behavior and the temperature profiles for the inlet, outlet, and storage tank during the day. The Gaussian profile presents a maximum $G_{b}$ was $987 \mathrm{~W} / \mathrm{m}^{2}$ in Cuernavaca city, this value is the highest value registered with respect to the reported previously. The evaluation was carried out for 5.5 h (9:30 a.m.-15:00 p.m.). In the stable section was presented between 12:17 p.m. to 14:45 p.m. It is very interesting the behavior of the storage tank temperature, because it was kept constant during $5.5 \mathrm{~h}$. The average storage tank temperature was $96.0^{\circ} \mathrm{C}$ and the maximum outlet temperature of HTF was $102.6^{\circ} \mathrm{C}$.

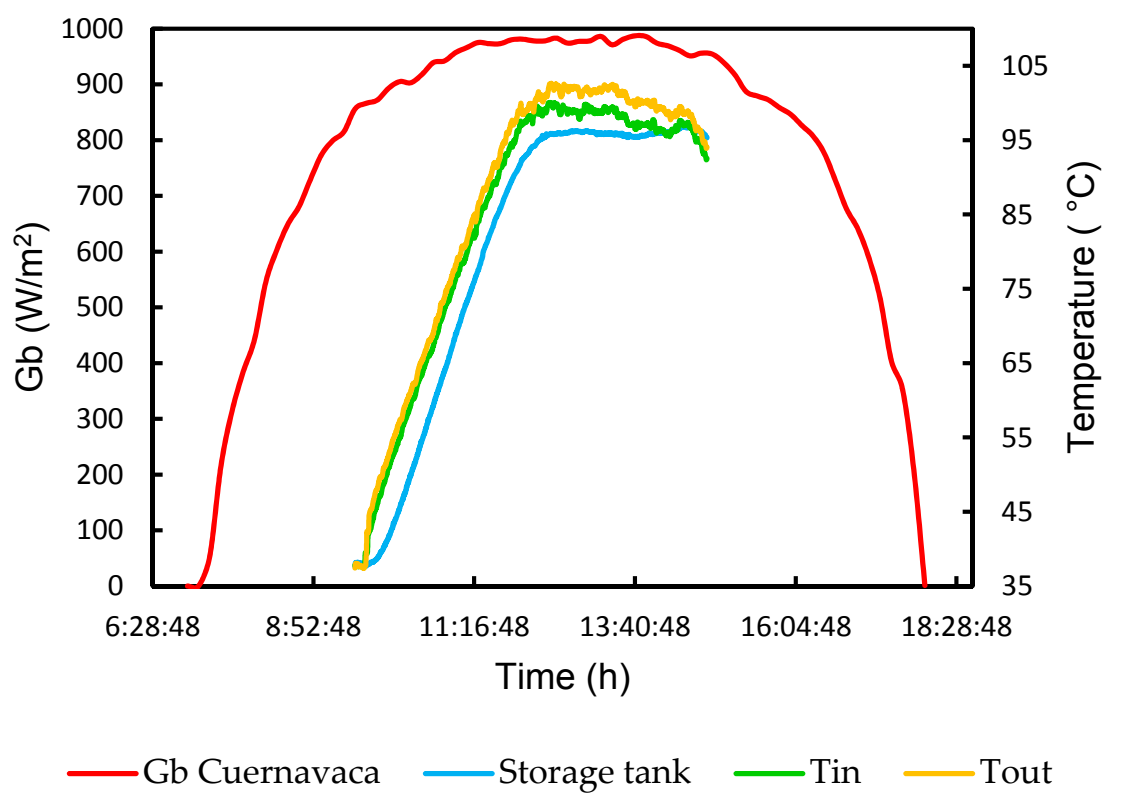

Figure 10. Behavior $G_{b}$ and outlet, inlet and storage tank temperatures, 11 December 2017. 
The analysis of thermal efficiency and useful heat are presented in Figure 11. It shows the behavior of thermal efficiency for the stable section (9:30 a.m.-15:00 p.m.), for which the maximum value calculated was $15.80 \%$ and the minimum was $8.05 \%$. The useful heat behavior varied in a range from $2.95 \mathrm{~kW}$ to $5.98 \mathrm{~kW}$, the $G_{b}$ was registered between $981 \mathrm{~W} / \mathrm{m}^{2}$ and $954 \mathrm{~W} / \mathrm{m}^{2}$. The decreasing trend in the useful energy is associated with the proximity of this temperature to the boiling temperature in the city of Cuernavaca. The exergy efficiency follows the same trend than others parameters, varying from 7.8 to $15 \%$.

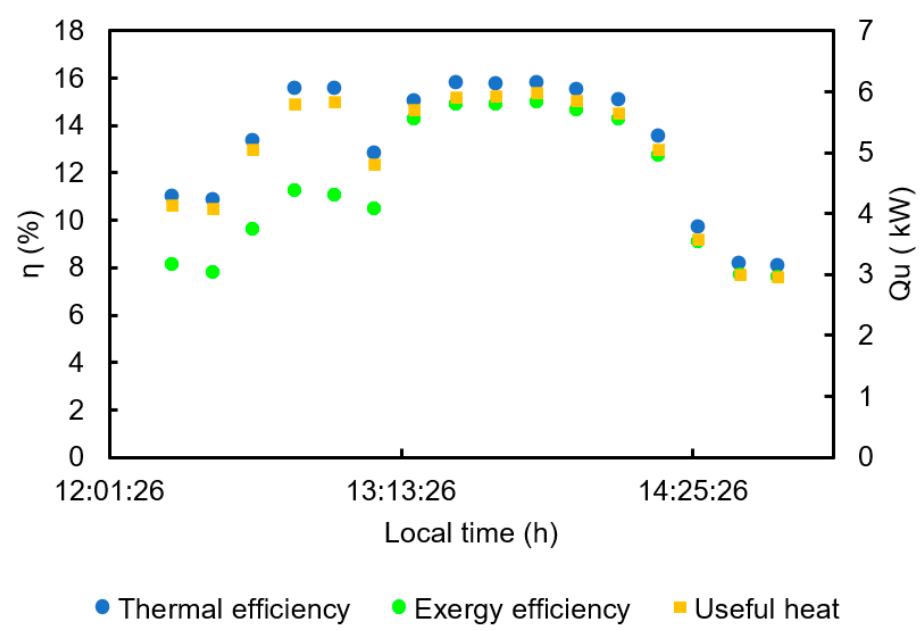

Figure 11. Thermal efficiency, exergy efficiency, and useful heat, 11 December 2017.

According to the results of the evaluation of solar collectors, the outlet temperature data was used as inlet data of absorption cycle, the inlet temperature was in a range from 85 to $95^{\circ} \mathrm{C}$, according to the results of PTCs. The useful heat was considered to be supplied to the generator in a range from 1.9 to $6.5 \mathrm{~kW}$.

In Figure 12, a comparison of the theoretical and experimental useful heat for the collectors' field is presented for one typical day. The figure shows a variation of $\mathrm{Qu}$ as a function of the test time. The theoretical maximum values were obtained at solar noon, when the value of the angle of incidence is zero. In Figure 12, the useful heat flux is affected by the global thermal losses estimated as $\left(U_{L}{ }^{\prime}\right) \times\left(A_{r}\right)=13.67 \mathrm{~W} / \mathrm{K}$. However, the negative trend for larger values of the angle of incidence is caused by the incidence angle modifier described by the Equation (3).

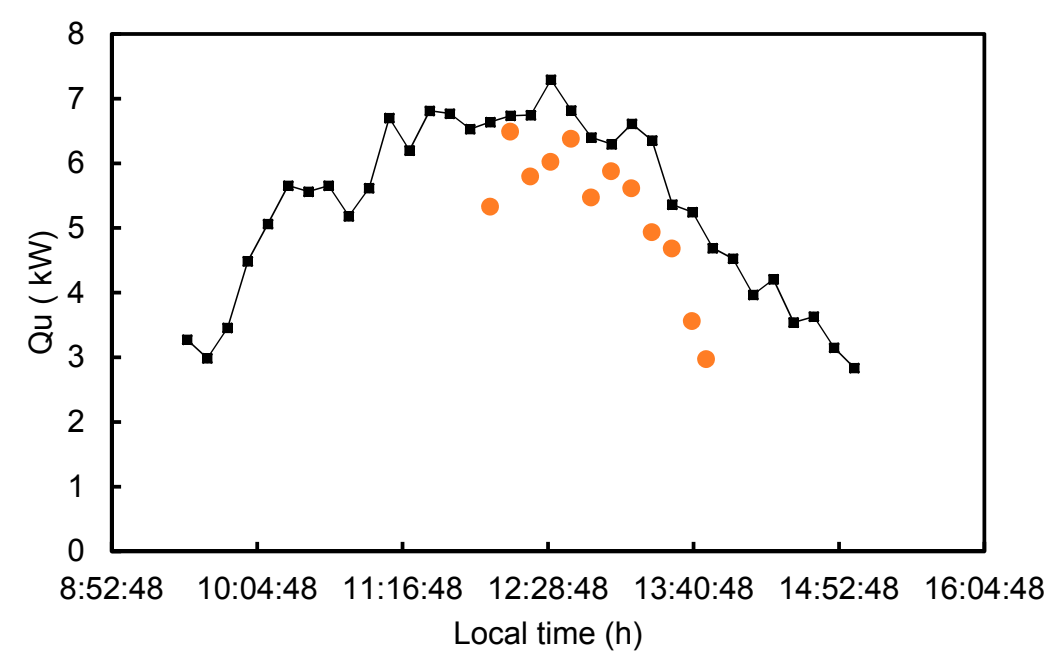

$\rightarrow-$ Theoretical Qu $\quad$ Experimental Qu

Figure 12. Theoretical and experimental useful heat in the solar collectors' field. 
Figures 13-16 show the experimental evaluation of absorption cooling system taking into account the previous results. Figure 13 shows the external generation power as a function of the heating water temperature, for several condensation water temperatures. In the presented curves it is possible to identify two sections: in the first one, the thermal power increases linearly with the increases in the heating water temperature, this behavior is kept to a point where there is no increase in the thermal power, this point gives rise to the second section of the curves, in which the thermal power does not tend to present any change when the generation temperature is increased.

The generation temperatures in the initial zone of each curve represent the temperatures of the heating water to which the absorption refrigeration system can begin to operate, however, in this section, there is still potential for heat transfer to the solution, so the operation of the cooling system is recommended at a temperature outside this zone. The fact of operating the absorption system at a generation temperature where the slope of each curve changes, guarantees that the potential for the heat transfer (temperature difference) in the generator has been used effectively. Finally, in the second operation zone, it is observed that when the temperature of the generation water is increased, there is no increase in the thermal power transmitted to the solution.

As it can be seen in Figure 13, for the curves corresponding to a condensation water temperature at $26^{\circ} \mathrm{C}$ and $28^{\circ} \mathrm{C}$, the condition in which the cooling power reaches its maximum is not perceived. This is due, because, for these curves, this point is above the range of generation temperatures considered. Figure 13 is very important to determine at what temperature the hot water is expected to be supplied to the system generator, in order to get an acceptable performance from the absorption cooling system, this temperature depends on the available condensation water temperature.

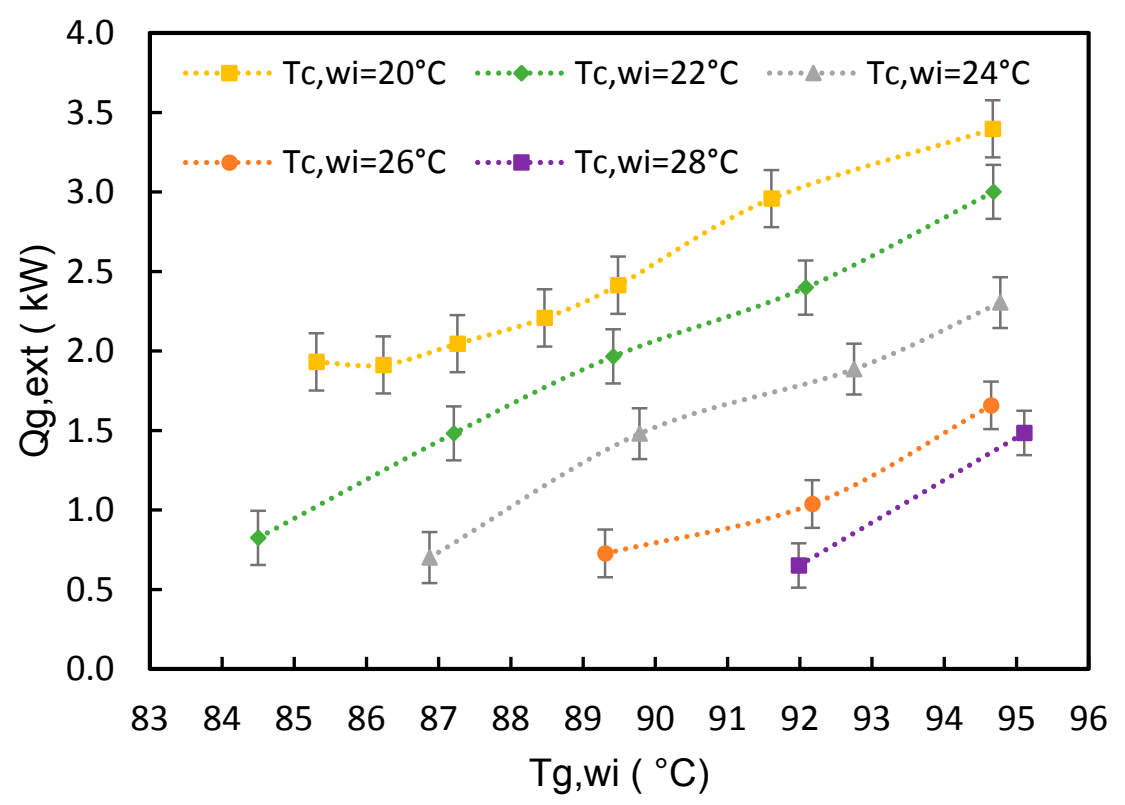

Figure 13. Generation power as a function of the generation temperature.

In Figure 14, the external generation power is plotted as a function of the external cooling power. In this figure, it can be seen that for each condensation temperature shown, there is an approximately linear relationship between these variables. This figure shows that, for the range of operating conditions shown (condensation water temperature), a linear function can be found that relates the required generation power to the desired cooling power. 


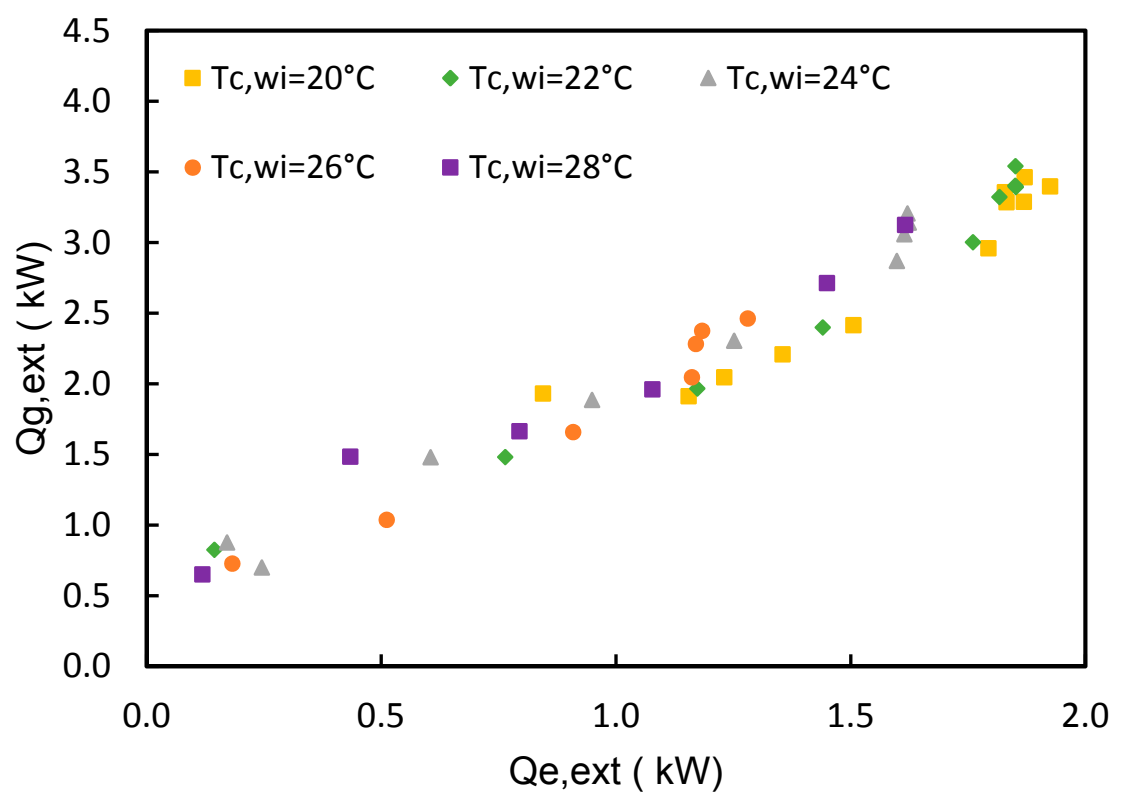

Figure 14. Variation of the generation and cooling powers for the different condensation temperatures.

Figure 15 shows the variation of the external coefficient of performance as a function of the external heating power, for each condensation temperature. From this figure it is observed that for each curve, as the heating power increases, the COP initially presents an increasing trend, after that, it reaches a maximum point and subsequently decreases with the increase in the heating power. It is worth mentioning that since during the tests reported, the solution mass flow rate was maintained constant through the system generator, so the increase in thermal power is due to an increase in the generation water temperature.

Figure 15 shows that, regarding the amount of heat supplied in the system generator, there is a limit that is not convenient to exceed since the performance of the absorption cooling system will be affected negatively, this is due to the fact that, experimentally in the generator, a thermal energy supply beyond the maximum point does not produce an equivalent cooling effect, so the coefficient of performance is reduced.

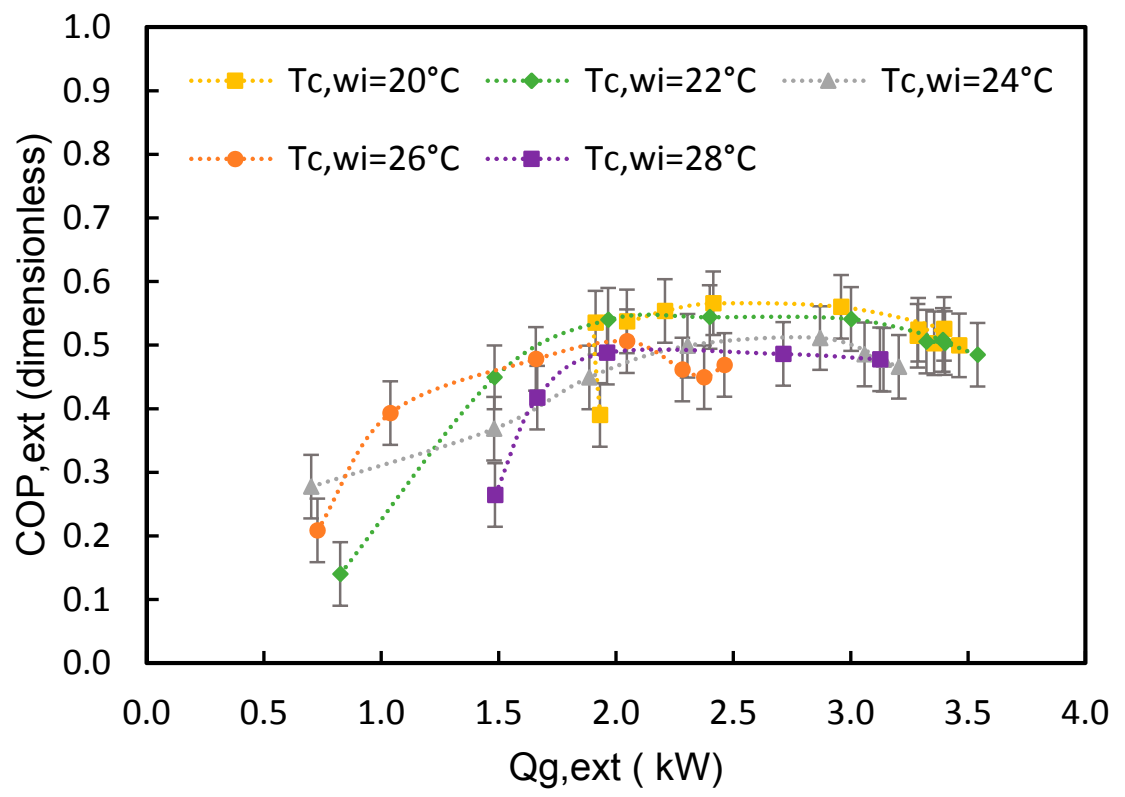

Figure 15. Behavior of the external coefficient of performance $(\mathrm{COP})$ as a function of the generation power. 
Finally, Figure 16, shows the variation in internal and external coefficients of performance as well as the exergy efficiency for the absorption cooling system, as a consequence of the simultaneous variation in the temperatures of the heating water and the water to be chilled in the evaporator. It is observed that during the experimental test, the internal coefficient of performance showed a slightly increasing trend, which is due to the effect of increasing the temperature of the heating water. On the other hand, the curve corresponding to the external COP shows a downward trend, which indicates that this parameter is more sensitive to the changes in the temperature of the water to be chilled than to the changes in the heating water temperature. The exergy efficiency was calculated using exclusively external parameters. Figure 16 demonstrates that the highest exergy efficiency is obtained when the heating water temperature is minimum, in spite of the temperature of the water to be chilled, this fact would suggest that the higher generation temperatures the higher exergy destruction is obtained.

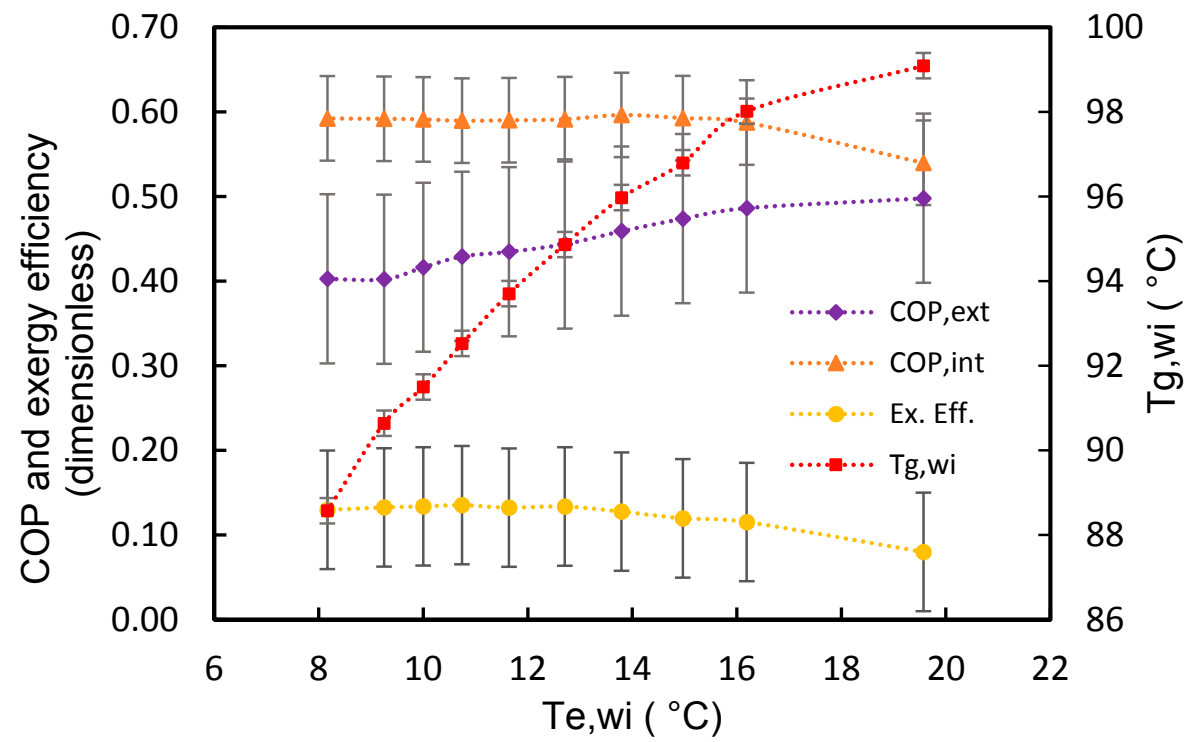

Figure 16. COP and exergy efficiency variation as a function of the change in the temperatures of the chilled and heating water.

In Table 5, the values for the solar coefficient of performance as well as the exergy efficiency at a condensation water temperature of $20^{\circ} \mathrm{C}$ are presented.

Table 5. Expected performance parameters for the combined system.

\begin{tabular}{ccc}
\hline & Solar COP & Exergy Efficiency \\
\hline Minimum value & 0.023 & $1.3 \times 10^{-3}$ \\
Maximum value & 0.070 & $4.4 \times 10^{-3}$ \\
\hline
\end{tabular}

On the other hand, the mean daily efficiency and cooling production that would be achieved with the combined system, is presented in Table 6 . These values were calculated taking into account the solar irradiance gained during the tests presented in this section, as well as the period of time during which the heating fluid temperature in the tank was constant. Moreover, it was considered that the temperature registered in the storage tank was the fluid temperature at the inlet port of the generator. This consideration implies that there is not any heat transfer from the fluid to the surroundings in the connection pipeline from the storage tank to the absorption cooling system, it could be a reasonable consideration if the pipeline is thermally insulated. The values in this table correspond to a condensation water temperature of $20^{\circ} \mathrm{C}$. 
Table 6. Values for a daily operation of the combined system.

\begin{tabular}{ccccc}
\hline Test & Lapse of Steady Operation & Mean Temperature Achieved & Mean Solar COP & Cooling Production \\
\hline 24 November & $120 \mathrm{~min}$ & $97.2^{\circ} \mathrm{C}$ & 0.057 & $13.55 \mathrm{MJ}$ \\
29 November & $180 \mathrm{~min}$ & $96.9^{\circ} \mathrm{C}$ & 0.062 & $20.26 \mathrm{MJ}$ \\
5 December & $120 \mathrm{~min}$ & $96.8^{\circ} \mathrm{C}$ & 0.050 & $13.5 \mathrm{MJ}$ \\
11 December & $330 \mathrm{~min}$ & $96.0^{\circ} \mathrm{C}$ & 0.058 & $36.78 \mathrm{MJ}$ \\
\hline
\end{tabular}

\section{Conclusions}

This investigation proposes the integration of a parabolic-trough collector field and an absorption cooling system, developed and evaluated separately. The solar collector field was evaluated in clear and cloudy days and it was shown that it can produce up to $6.5 \mathrm{~kW}$ of useful heat at temperatures as high as $105^{\circ} \mathrm{C}$. On the other hand, the absorption cooling system was developed using plate heat exchangers as the main components. The cooling system operated with the ammonia-lithium nitrate mixture, and was evaluated at different heat-source and condensation temperatures. The meaningful values achieved with the independent systems are the following:

- The solar system can provide useful heat at rates from 1.9 to $6.5 \mathrm{~kW}$ at temperatures suitable for driving a single-stage absorption cooling system.

- The thermal efficiencies for the solar system varied from $8 \%$ to $19.8 \%$.

- The cooling powers achieved with the absorption system varied between 0.11 and $1.92 \mathrm{~kW}$, when the supplied heat in the generator was from 0.67 to $3.4 \mathrm{~kW}$, respectively.

- It was demonstrated the exergy efficiency for the cooling system increases when the heating water temperature decreases.

- The external coefficient of performance achieved with the absorption system varied from 0.14 to 0.56 .

Once the integration of both systems is performed, the expected values for the solar coefficient of performance are in the range from 0.023 to 0.070 . From the obtained results, it is possible to conclude that the proposed solar absorption cooling system will be able to be applied in air-conditioning applications offering a reasonable performance.

Author Contributions: Y.R.G.L. \& R.J.R.D. have modeled and evaluated the solar plant for several operating conditions theoretical previously and experimentally in situ absorption cycle assessment. W.R.G.F. \& J.C.J.G. carried out the design and evaluation of the absorption device. U.D.C. evaluated the solar devices and the instrumentation uncertainty analysis.

Funding: This research was funded by the fondo sectorial: SENER-CONACYT "Sustentabilidad energética" grant number CeMIE-SOL-09. The APC was funded by the CONACYT through the project "879 Proyectos de desarrollo científico para atender problemas nacionales 2014".

Acknowledgments: The authors express their gratitude to Red SUMAS, project: 293876 funded by CONACYT, Mexico. U. Dehesa-Carrasco wishes to thank IMTA for the "1772 Cátedras CONACYT México" project. Yuridiana Galindo appreciates the economical support provided by the project CIC 2018 UNAM. Also the authors express their gratitude to Eduardo Venegas Reyes for its help in this work.

Conflicts of Interest: The authors declare having no conflict of interest.

\section{References}

1. Shin, M.; Do, S.L. Prediction of cooling energy use in building using an enthalpy-based cooling degree days method in a hot and humid climate. Energy Build. 2016, 110, 57-70. [CrossRef]

2. Vidal-Zepeda, R. Las Regiones Climáticas de México; Temas selectos de Geografía de México, Investigaciones geográficas, Instituto de Geografía: México, D.F., Mexico, 2005; pp. 137-138, ISBN 970-32-2394-X.

3. Oropeza-Perez, I.; Østergaard, P.A. Energy saving potential by utilizing natural ventilation in warm conditions-a case of Mexico. Appl. Energy 2014, 130, 20-32. [CrossRef]

4. Rosas-Flores, J.A.; Rosas-Flores, D.; Gálvez, D.M. Saturation, energy consumption $\mathrm{CO}_{2}$ emission and energy efficiency from urban and rural households appliances in Mexico. Energy Build. 2011, 43, 10-18. [CrossRef] 
5. Oropeza-Perez, I. Comparative economic assessment of the energy performance of air-conditioning within the Mexican residential sector. Energy Rep. 2016, 2, 147-154. [CrossRef]

6. Hernández-Escobedo, Q.; Rodríguez-García, E.; Saldaña-Flores, R.; Fernández-García, A.; Manzano-Agugliaro, F. Solar energy resource assessment in Mexican states along the Gulf of Mexico. Renew. Sustain. Energy Rev. 2015, 43, 216-238. [CrossRef]

7. Coccia, G.; Di Nicola, G.; Hidalgo, A. Parabolic Trough Collector Prototypes for Low-Temperature Process Heat; Applied Sciences and Technology; Springer: Berlin, Germany, 2016. [CrossRef]

8. Li, Z.F.; Sumathy, K. Experimental studies on a solar-powered air conditioning system with partitioned hot water storage tank. Sol. Energy 2001, 71, 285-297. [CrossRef]

9. Syed, A.; Izquierdo, M.; Rodríguez, P.; Maidment, G.; Missenden, J.; Lecuona, A.; Tozer, R. A novel experimental investigation of a solar cooling system in Madrid. Int. J. Refrig. 2005, 28, 859-871. [CrossRef]

10. Rodríguez-Hidalgo, M.C.; Rodríguez Aumente, P.; Izquierdo Millán, M.; Leucona Neumann, A.; Salgado Mangual, R. Energy and carbón emission savings in Spanish housing air-conditioning using solar driven absorption system. Appl. Therm. Eng. 2008, 28, 1734-1744. [CrossRef]

11. Rosiek, S.; Batlles, F.J. Integration of the solar thermal energy in the construction: Analysis of the solar-assisted air-conditioning system installed in CIESOL building. Renew. Energy 2009, 24, 1423-1431. [CrossRef]

12. Mac, O.; Lucas, F.; Sinama, F.; Monceyron, E. Experimental investigation of a solar cooling absorption system operating without any backup system under tropical climate. Energy Build. 2010, 42, 774-782. [CrossRef]

13. Sanjuan, C.; Soutullo, S.; Heras, M.R. Optimization of a solar cooling system with interior energy storage. Sol. Energy 2010, 84, 1244-1254. [CrossRef]

14. González_Gil, A.; Izquierdo, M.; Marcos, J.D.; Palacios, E. Experimental evaluation of a direct air-cooled lithium bromide-water absorption prototype for solar air conditioning. Appl. Therm. Eng. 2011, 31, 3358-3368. [CrossRef]

15. Martínez, P.J.; Martínez, J.C.; Lucas, M. Design and test results of a low-capacity solar cooling system in Alicante (Spain). Sol. Energy 2012, 86, 2950-2960. [CrossRef]

16. Zhai, X.; Li, Y.; Cheng, X.; Wang, R. Experimental investigation on a solar-powered absorption radiant cooling system. Energy Procedia 2015, 70, 552-559. [CrossRef]

17. Sun, H.; Xu, Z.; Wang, H.; Wang, R. A solar/gas fired absorption system for cooling and heating in a commercial building. Energy Procedia 2015, 70, 518-528. [CrossRef]

18. Galindo-Luna, Y.R.; Gómez-Arias, E.; Romero, R.J.; Venegas-Reyes, E.; Montiel-González, M.; Unland-Weiss, E.; Pacheco Hernández, P.; González-Fernández, A.; Díaz-Salgado, J. Hybrid solar-geothermal energy absorption air-conditioning system operating with $\mathrm{NaOH}-\mathrm{H}_{2} \mathrm{O}$-Las Tres Vírgenes (Baja California Sur), "La Reforma” case. Energies 2018, 11, 1268. [CrossRef]

19. Bellos, E.; Tzivanidis, C.; Antonopoulos, K.A. Exergetic and energetic comparison of $\mathrm{LiCl}_{-} \mathrm{H}_{2} \mathrm{O}$ and $\mathrm{LiBr}-\mathrm{H}_{2} \mathrm{O}$ working pairs in a solar absorption cooling system. Energy Convers. Manag. 2016, 123, 453-461. [CrossRef]

20. Patel, J.; Pandya, B.; Mudgal, A. Exergy Based Analysis of $\mathrm{LiCl}-\mathrm{H}_{2} \mathrm{O}$ Absorption Cooling System. Energy Procedia 2017, 109, 261-269. [CrossRef]

21. Aman, J.; Henshaw, P.; Ting, D.S. Bubble-pump-driven $\mathrm{LiBr}-\mathrm{H}_{2} \mathrm{O}$ and $\mathrm{LiCl}-\mathrm{H}_{2} \mathrm{O}$ absorption air-conditioning systems. Therm. Sci. Eng. Prog. 2018, 6, 316-322. [CrossRef]

22. Bellos, E.; Tzivanidis, C.; Pavlovic, S.; Stefano, V. Thermodynamic investigation of $\mathrm{LiCl}-\mathrm{H}_{2} \mathrm{O}$ working pair in a double effect absorption chiller driven by parabolic trough collectors. Therm. Sci. Eng. Prog. 2017, 3, $75-87$. [CrossRef]

23. Konwar, D.; Gogo, T.K. Performance of double effect $\mathrm{H}_{2} \mathrm{O}-\mathrm{LiCl}$ absorption refrigeration systems and comparison with $\mathrm{H}_{2} \mathrm{O}-\mathrm{LiBr}$ systems, Part 1: Energy analysis. Therm. Sci. Eng. Prog. 2018, 8, 184-203. [CrossRef]

24. Konwar, D.; Gogo, T.K. Performance of double effect $\mathrm{H}_{2} \mathrm{O}-\mathrm{LiCl}$ absorption refrigeration systems and comparison with $\mathrm{H}_{2} \mathrm{O}-\mathrm{LiBr}$ systems, Part 2: Energy analysis. Therm. Sci. Eng. Prog. 2018, 8, 171-183. [CrossRef]

25. Best, R.; Rivera, W. A review of thermal cooling systems. Appl. Therm. Eng. 2015, 75, 1162-1175. [CrossRef]

26. Rivera, W.; Best, R.; Cardoso, M.J.; Romero, R.J. A review of absorption heat transformers. Appl. Therm. Eng. 2015, 91, 654-670. [CrossRef] 
27. Wu, W.; Zhang, X.L.; Li, X.T.; Shi, W.X.; Wang, B.L. Comparisons of different working pairs and cycles on the performance of absorption heat pump for heating and domestic hot water in cold regions. Appl. Therm. Eng. 2012, 48, 349-358. [CrossRef]

28. Wu, W.; Wang, B.; Shi, W.; Li, X. Crystallization analysis and control of ammonia-based air source absorption heat pump in cold regions. Adv. Mech. Eng. 2013, 5, 140341. [CrossRef]

29. Boman, D.B.; Hoysall, D.C.; Staedter, M.A.; Goyal, A.; Ponkala, M.J.; Garimella, S. A method for comparison of absorption heat pump working pairs. Int. J. Refrig. 2017, 77, 149-175. [CrossRef]

30. Wang, J.F.; Gao, G.C.; Chen, G.M. An improved absorption refrigeration cycle driven by unsteady thermal sources below $100{ }^{\circ} \mathrm{C}$. Int. J. Energy Res. 2000, 24, 633-640. [CrossRef]

31. Rivera, W.; Moreno-Quintanar, G.; Rivera, C.O.; Best, R.; Martínez, F. Evaluation of a solar intermittent refrigeration system for ice production operating with ammonia/lithium nitrate. Sol. Energy 2011, 85, 38-45. [CrossRef]

32. Moreno-Quintanar, G.; Rivera, W.; Best, R. Comparison of the experimental evaluation of a solar intermittent refrigeration system for ice production operating with the mixtures $\mathrm{NH}_{3}-\mathrm{LiNO}_{3}$ and $\mathrm{NH}_{3}-\mathrm{LiNO}_{3}-\mathrm{H}_{2} \mathrm{O}$. Renew. Energy 2012, 38, 62-68. [CrossRef]

33. Llamas, S.U.; Herrera, J.V.; Cuevas, R.; Gómez, V.H.; García-Valladares, O.; Cerezo, J.; Best, R. Development of a small capacity ammonia-lithium nitrate absorption refrigeration system. In Proceedings of the 2nd International Conference on Solar Air-Conditioning, Tarragona, Spain, 18-19 October 2007; pp. 470-475.

34. Llamas, S.U.; Cuevas, R.; Best, R.; Gómez, V.H. Experimental results of a direct air-cooled ammonia-lithium nitrate absorption refrigeration system. Appl. Therm. Eng. 2014, 67, 362-369. [CrossRef]

35. Zamora, M.; Bourouis, M.; Coronas, A.; Vallès, M. Pre-industrial development and experimental characterization of new air-cooled and water-cooled ammonia/lithium nitrate absorption chillers. Int. J. Refrig. 2014, 45, 189-197. [CrossRef]

36. Zamora, M.; Bourouis, M.; Coronas, A.; Vallès, M. Part-load characteristics of a new ammonia/lithium nitrate absorption chiller. Int. J. Refrig. 2015, 56, 46-51. [CrossRef]

37. Hernández-Magallanes, J.A.; Domínguez-Inzunza, L.A.; Gutiérrez-Urueta, G.; Soto, P.; Jiménez, C.; Rivera, W. Experimental assessment of an absorption cooling system operating with the ammonia/lithium nitrate mixture. Energy 2014, 78, 685-692. [CrossRef]

38. Domínguez-Inzunza, L.A.; Hernández-Magallanes, J.A.; Soto, P.; Jiménez, C.; Gutiérrez-Urueta, G.; Rivera, W. Experimental assessment of an absorption cooling system utilizing a falling film absorber and generator. Appl. Therm. Eng. 2019, 103, 1105-1111. [CrossRef]

39. Jaramillo, O.A.; Venegas-Reyes, E.; Aguilar, J.O.; Castrejón-García, R.; Sosa-Montemayor, F. Parabolic trough concentrator for low enthalpy processes. Renew. Energy 2013, 60, 529-539. [CrossRef]

40. Ibarra-Bahena, J.; Dehesa-Carrasco, U.; Montiel-González, M.; Romero, R.J.; Venegas-Reyes, E. Feasibility analysis of a hot water solar system coupled to an absorption heat transformer. Appl. Therm. Eng. 2017, 114, 1176-1185. [CrossRef]

41. Rabl, A. Active Solar Collectors and Their Applications; Oxford University Press: Evans Road Cary, NC, USA, 1985.

42. Jaramillo, O.A.; Aguilar, J.O.; Castrejón-García, R.; Venegas-Reyes, E.; Sosa-Montemayor, F. Parabolic trough concentrators for hot water generation: Comparison of the levelized cost of production. J. Renew. Sustain. Energy 2013, 5, 023114. [CrossRef]

43. MacPhee, D.; Dincer, I. Thermal modeling of a packed bed thermal energy storage system during charging. Appl. Therm. Eng. 2009, 29, 696-705. [CrossRef]

44. Petela, R. Exergy of undiluted thermal radiation. Sol. Energy. 2003, 74, 469-488. [CrossRef]

45. Dutta, G.K.K.; Saha, S.K. Energy analysis of solar thermal collectors. Renew. Energy Environ. 1990, 33, 283-287.

46. Chafie, M.; Ben Aissa, M.F.; Guizani, A. Energetic end exergetic performance of a parabolic trough collector receiver: An experimental study. J. Clean. Prod. 2018, 71, 285-296. [CrossRef]

(C) 2018 by the authors. Licensee MDPI, Basel, Switzerland. This article is an open access article distributed under the terms and conditions of the Creative Commons Attribution (CC BY) license (http:/ / creativecommons.org/licenses/by/4.0/). 